\title{
Recent Progress in Applications of Enzymatic Bioelectrocatalysis
}

\author{
Taiki Adachi, Yuki Kitazumi, Osamu Shirai and Kenji Kano *, $+\mathbb{D}$ \\ Division of Applied Life Sciences, Graduate School of Agriculture, Kyoto University, Sakyo, \\ Kyoto 606-8502, Japan; adachi.taiki.62s@st.kyoto-u.ac.jp (T.A.); kitazumi.yuki.7u@kyoto-u.ac.jp (Y.K.); \\ shirai.osamu.3x@kyoto-u.ac.jp (O.S.) \\ * Correspondence: kano.kenji.5z@kyoto-u.ac.jp \\ + Present address: Center for Advanced Science and Innovation, Kyoto University, Gokasho, Uji, \\ Kyoto 611-0011, Japan.
}

Received: 15 November 2020; Accepted: 1 December 2020; Published: 3 December 2020

\begin{abstract}
Bioelectrocatalysis has become one of the most important research fields in electrochemistry and provided a firm base for the application of important technology in various bioelectrochemical devices, such as biosensors, biofuel cells, and biosupercapacitors. The understanding and technology of bioelectrocatalysis have greatly improved with the introduction of nanostructured electrode materials and protein-engineering methods over the last few decades. Recently, the electroenzymatic production of renewable energy resources and useful organic compounds (bioelectrosynthesis) has attracted worldwide attention. In this review, we summarize recent progress in the applications of enzymatic bioelectrocatalysis.
\end{abstract}

Keywords: bioelectrocatalysis; nanostructured electrodes; protein engineering; bioelectrosynthesis; photo-bioelectrocatalysis

\section{Introduction}

Oxidoreductases catalyze redox reactions between two sets of redox substrate couples and are considered industrially useful catalysts due to their high activities and substrate specificities under mild conditions (room temperature, normal pressure, and neutral $\mathrm{pH}$ ). However, most oxidoreductases, in addition to nicotinamide cofactor $(\mathrm{NAD}(\mathrm{P}))$-dependent enzymes, show low substrate specificities for one of the substrates. Such redox enzymes can accept or donate electrons from or to electrodes directly or via artificial redox mediators. The coupled reaction is called bioelectrocatalysis, and the catalytic function of the redox enzymes provides a variety of specific and strong catalytic activities to nonspecific electrode reactions. [1-5]. Bioelectrocatalysis provides a firm base for characterizing redox enzyme reactions and applying the concept and related technologies to useful bioelectrochemical devices such as biosensors [6-14], biofuel cells [11,15-21], biosupercapacitors [22], and other bioreactors [23].

Bioelectrocatalytic reactions are classified into two types according to the mode of the electron transfer described above: direct electron transfer (DET) and mediated electron transfer (MET), as shown in Figure 1. These reactions proceed in the following schemes in the simple case of the substrate's oxidation. On the other hand, we note here that some redox enzymes that have a catalytic site alone, without any other redox site(s), are also able to show DET-type bioelectrocatalysis, e.g., cytochrome $c$ peroxidase [24], horseradish peroxidase (HRP) [25-27], ferredoxin-NADP ${ }^{+}$reductase [28], flavin adenine dinucleotide (FAD)-dependent glucose oxidase (FAD-GOD) [29,30], and FAD-dependent glucose dehydrogenase (FAD-GDH) [31]. 


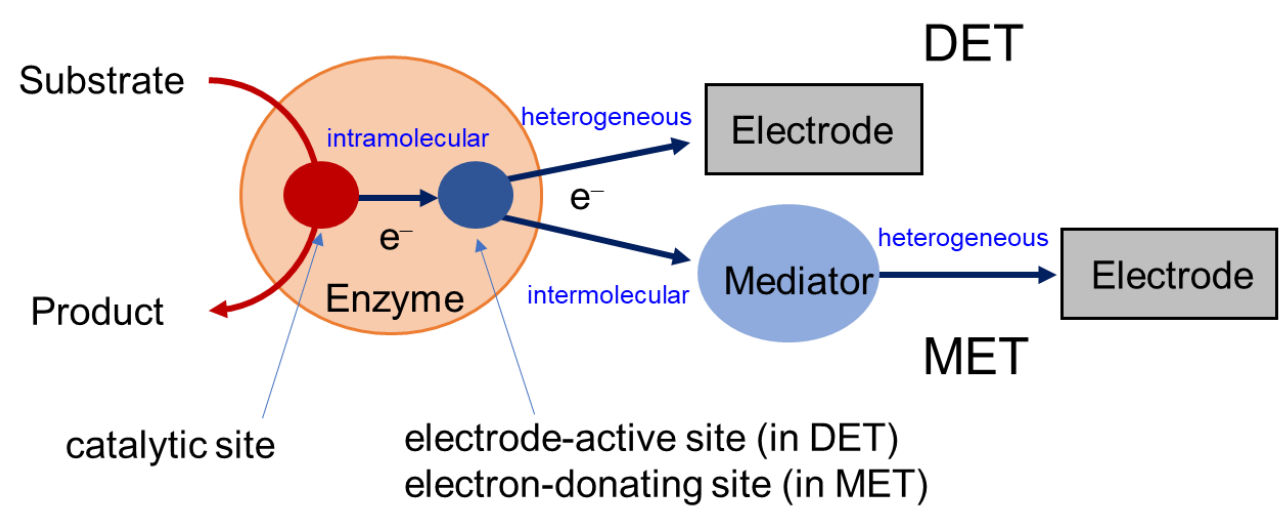

Figure 1. Schematic of electron transfer processes in direct electron transfer (DET)- and mediated electron transfer (MET)-type bioelectrocatalysis for substrate oxidation. In this scheme, the enzyme is assumed to have both catalytic and electron-donating sites in the molecules.

The DET-type reaction is given by Equations (1) and (2):

$$
\mathrm{S}+\frac{n_{\mathrm{S}}}{n_{\mathrm{E}}} \mathrm{E}_{\mathrm{O}} \stackrel{\text { Enzyme }}{\longrightarrow} \frac{n_{\mathrm{S}}}{n_{\mathrm{P}}} \mathrm{P}+\frac{n_{\mathrm{S}}}{n_{\mathrm{E}}} \mathrm{E}_{\mathrm{R}}
$$

and

$$
\mathrm{E}_{\mathrm{R}} \stackrel{\text { Electrode }}{\rightleftarrows} \mathrm{E}_{\mathrm{O}}+n_{\mathrm{E}} \mathrm{e}^{-},
$$

On the other hand, the MET-type reaction is given by Equations (3) and (4):

$$
\mathrm{S}+\frac{n_{\mathrm{S}}}{n_{\mathrm{M}}} \mathrm{M}_{\mathrm{O}} \stackrel{\text { Enzyme }}{\longrightarrow} \frac{n_{\mathrm{S}}}{n_{\mathrm{P}}} \mathrm{P}+\frac{n_{\mathrm{S}}}{n_{\mathrm{M}}} \mathrm{M}_{\mathrm{R}}
$$

and

$$
\mathrm{M}_{\mathrm{R}} \stackrel{\text { Electrode }}{\rightleftarrows} \mathrm{M}_{\mathrm{O}}+n_{\mathrm{M}} \mathrm{e}^{-},
$$

where $\mathrm{S}, \mathrm{P}, \mathrm{E}$, and $\mathrm{M}$ indicate a substrate, a product, an enzyme, and a mediator, respectively. $n_{\mathrm{X}}$ is the number of electrons of the chemical species $X . X_{O}$ and $X_{R}$ are the oxidized and reduced forms of $\mathrm{X}$, respectively. In DET-type bioelectrocatalysis, it is easy to construct relatively simple systems with minimum overpotentials in the electron transfer between the electrode-active redox center of an enzyme and an electrode from the thermodynamic perspectives. In this review, the electrode-active redox center means the site that can directly communicate with electrodes and is assigned to the catalytic active site (especially for redox enzymes that have the catalytic site alone) or an electron-donating/accepting site (other than the catalytic center) that constitutes the intramolecular electron transfer. However, the reported redox enzymes enable DET-type reactions are increasing but still limited in number because the electrochemical communication between an enzyme and an electrode occurs only when the electrode-active cofactor of the enzyme is close in distance to the electrode surface [32-35]. In MET-type bioelectrocatalysis, on the other hand, a variety of enzymes can be used in principle, and a suitable selection of mediators makes it possible to construct realistic systems. In addition, once both enzymes and mediators are stably immobilized on electrodes, the measurement systems work as pseudo-DET-type systems [10,11,36]. Particularly, redox polymers anchoring osmium complexes [3,37-45], ferricyanide [46,47], metallocenes [48-51], and viologen units [52-55] are constructed as polymeric mediators immobilized on electrodes. In summary, a DET-type system is often more ideal than a MET-type system, whereas it seems to be practical to utilize an MET-type system for several objectives. 
The overpotential in bioelectrocatalysis has two components: (1) thermodynamics; the difference in the formal potential between the substrate and the electron-donating site, and (2) kinetics; slow kinetics in the heterogeneous electron transfer (Figure 1). There is no way to avoid the problem concerning the first issue as long as one utilizes natural enzymes. Slow kinetics in heterogeneous electron transfer is compensated by the so-called overpotential of the electrode in the DET-type reaction and by the large driving force (that is, increased difference in the formal potential) between the enzyme and mediator. In this review, we will describe several techniques for improving the performance of enzymatic bioelectrocatalytic systems and summarize recent studies on their applications.

\section{Tuning of Nanostructured Electrodes and Protein-Engineering of Redox Enzymes}

\subsection{Electrode Nanomaterials}

In DET-type and enzyme/mediator-immobilized MET-type bioelectrocatalysis, immobilization of as many amounts of enzymes and mediators as possible on the electrode surface is, in principle, able to increase the current density of bioelectrocatalytic systems. Therefore, nanostructured electrodes with a large ratio of the effective surface area against the projective surface area are useful and frequently utilized for bioelectrocatalytic systems. In addition, it is suggested that the heterogeneous electron transfer kinetics at the top edge of the microstructures of these electrodes is accelerated by the electric field strengthened by the expansion of the electric double layer [56] and the charge accumulation as expected by the Poisson equation [4]. This effect is very useful to decrease the overpotential due to the heterogeneous electron transfer in the DET-type reaction.

Electrode nanomaterials utilized in bioelectrocatalysis are roughly divided into two classes: carbon and metal. Carbon nanomaterials, such as carbon nanotubes [57-59], carbon blacks [60], carbon cryogels [61,62], and MgO-templated carbons [43,63,64], have properties to physically adsorb a large amount of enzymes and mediators at hydrophobic sites and are generally used as platforms favorable for bioelectrocatalysis. On the other hand, nanoporous gold constructed by anodization [27,65-67] or dealloying [68-70] and metallic nanoparticles of gold [57,71-78], silver [79-81], platinum [29-31], titanium oxide $\left(\mathrm{TiO}_{2}\right)[80,81]$, iron oxide $\left(\mathrm{Fe}_{2} \mathrm{O}_{3}\right)[82,83]$, and indium tin oxide (ITO) [84] are also widely used. Compared to carbon nanomaterials, the pore and particle sizes of metallic nanomaterials can be easily controlled according to several manufacturing methods. In addition, conductive supports, such as polymer hydrogels, act as nanostructured electrodes [85].

Furthermore, nanostructured electrodes exert another positive effect on DET-type bioelectrocatalysis from the viewpoint of the enzyme's orientation. The limited catalytic current density $\left(j_{\text {cat }}\right)$ in DET-type reactions is expressed by Equation (5):

$$
j_{\mathrm{cat}}= \pm n_{\mathrm{E}} F k_{\mathrm{c}, \mathrm{DET}} \Gamma_{\mathrm{E}, \mathrm{eff}}
$$

where $F$ is the Faraday constant, $k_{\mathrm{c}, \mathrm{DET}}$ is the catalytic constant in DET-type bioelectrocatalysis (with $k_{\mathrm{c}, \mathrm{DET}}=\left(n_{\mathrm{S}} / n_{\mathrm{E}}\right) k_{\mathrm{c}, \mathrm{DET}(1)}, k_{\mathrm{c}, \mathrm{DET}(1)}$ being the catalytic constant for single turnover of the enzyme), and $\Gamma_{\mathrm{E}, \text { eff }}$ is the surface concentration of the effective enzyme. Here, "effective" means being able to electrochemically communicate with electrodes. In other words, enzymes of which the electrode-active sites face away from the electrode are not included because the long-range electron transfer kinetic constant $\left(\mathrm{k}^{\circ}\right)$ exponentially decreases with an increase in the distance between the electrode surface and the electrode-active site in an enzyme (d) [86-88], as described by Equation (6):

$$
\mathrm{k}^{\circ}=\mathrm{k}_{\max }^{\circ} \exp (-\beta \mathrm{d})
$$

where $\mathrm{k}^{\circ}{ }_{\max }$ is the rate constant at the closest approach $\left(\mathrm{d}=\mathrm{d}_{\min }\right)$ and $\beta$ is the decay coefficient. Based on the random orientation model in which enzymes are assumed to be randomly oriented on electrodes $[32,89,90]$, the enzymes can penetrate into nanostructured electrodes with mesopores, and the mesoporous electrodes can adsorb a large amount of enzymes suitable for DET-type reactions 
compared with planar electrodes, as illustrated in Figure 2. This is called the curvature effect of mesoporous electrodes for DET-type bioelectrocatalysis and is also very effective in decreasing the overpotential of DET-type bioelectrocatalysis. In practical applications, it is necessary to select and optimize electrode nanomaterials based on the estimated size, shape, and hydrophobicity of enzymes.

(A) Planar electrode

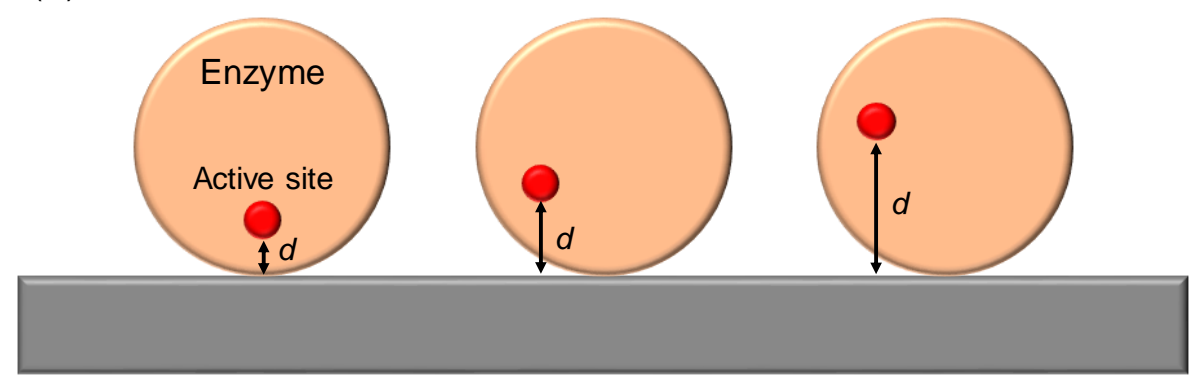

(B) Mesoporous electrode

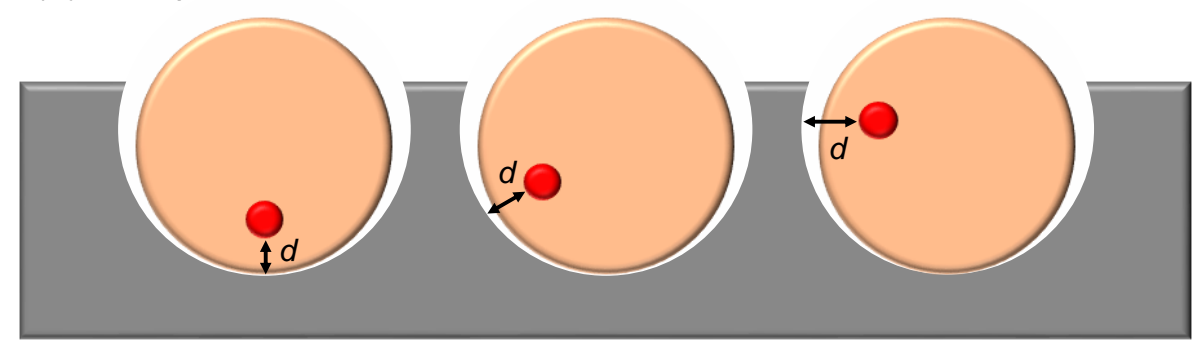

Figure 2. Schematic of the enzyme orientations at the (A) planar and (B) mesoporous electrodes.

On the other hand, chemical modifications of electrode surfaces are very effective in controlling the enzyme orientation by electrostatic or other specific interactions between the electrode-active site and the electrode surface; therefore, they are useful to increase the population of the enzyme orientations with minimum distances between the electrode-active site and the electrode surface [91]. Such favorite orientations also contribute to decreasing the overpotential in the DET-type reaction. For example, [NiFe]-hydrogenase $\left(\mathrm{H}_{2}\right.$ ase) from Desulfovibrio vulgaris Miyazaki F and copper efflux oxidase (CueO) expressed in Escherichia coli showed strong DET-type bioelectrocatalysis activity at (positively charged) $p$-phenylenediamine-functionalized Ketjen-Black-modified glassy carbon electrodes compared with Ketjen-Black-modified electrode without any chemical functionalization and artificially introduced charged groups. The surfaces near the electrode-active sites of the enzymes are estimated to be negatively charged and the attractive electrostatic interaction with positively charged electrode surfaces increases the probability of enzyme orientations favorable for the interfacial electron transfer [92,93].

In contrast, bilirubin oxidase (BOD) from Myrothecium verrucaria showed strong DET-type bioelectrocatalytic activity at negatively charged electrodes. The surface near the electrode-active site of the enzyme is positively charged and the electrostatic interaction with negatively charged electrodes increases the probability of favorable orientations of the enzyme [94]. On the other hand, the DET-type bioelectrocatalysis of BOD was also improved by modifying an electrode with bilirubin (as the natural electron donor), which seemed to attractively interact with the electrode-active type I copper site as the electron-accepting site. The interaction increases the probability of favorable orientations of the enzyme [95]. In addition, membrane-bound D-fructose dehydrogenase (FDH) from Gluconobacter japonicus NBRC3260 showed strong DET-type bioelectrocatalytic activity at a 4-mercaptophenol-modified porous gold electrode, probably due to the stabilization of the enzyme layer by the hydroxy groups of 4-mercaptophenol [96]. FDH also showed the attractive and specific interaction with methoxy substituents on the electrode surface, which resulted in the favorable orientation [97]. 
In addition, gas-diffusion bioelectrodes are effective for enzymatic bioelectrocatalysis in which gaseous substrates such as dihydrogen, dioxygen, and carbon dioxide were used [98]. Since these gasses have low water solubility, the bioelectrocatalytic currents are often controlled and limited by diffusion processes of the substrates at usual electrodes. On the other hand, gas-diffusion bioelectrodes realize direct supplies of gaseous substrates from the gas phase to the reaction layer due to their suitable conductivity, hydrophobicity/hydrophilicity balance, and gas permeability, as illustrated in Figure 3.

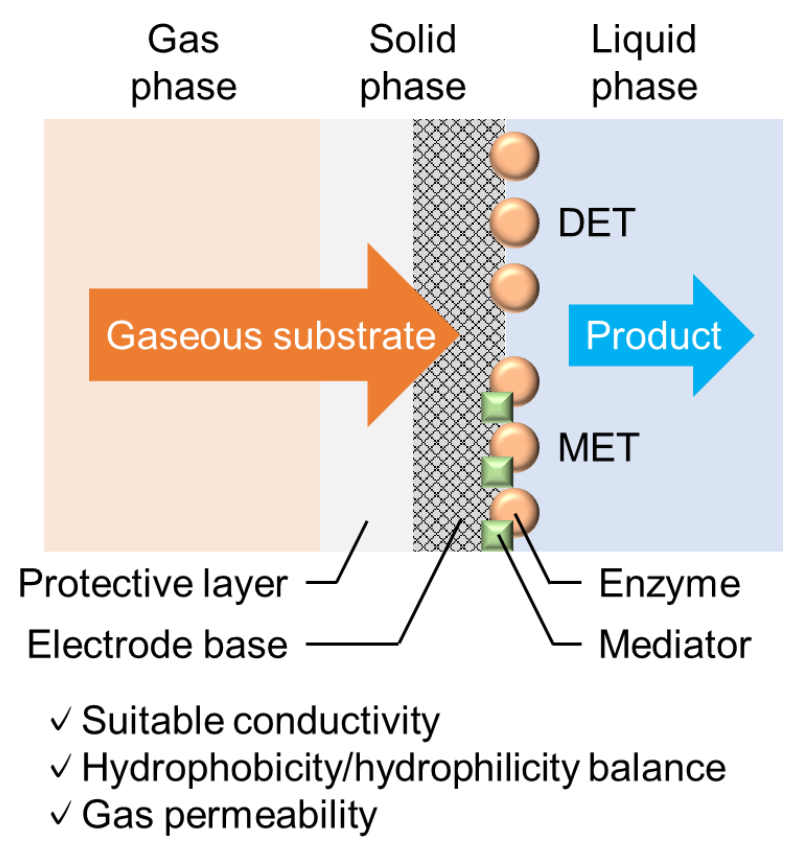

Figure 3. Schematic of a bio-three-phase interface of a gas-diffusion bioelectrode.

\subsection{Protein-Engineering Approaches}

Bioelectrocatalysis can be improved not only by functionalizing electrodes but also by engineering enzymes. Based on the crystal structure of enzymes, various mutations can be introduced into redox enzymes by protein-engineering methods [21,99].

\subsubsection{Formal Potential Shift of Electrode-Active Sites}

The negative shift of the formal potential of the electron-donating site for the substrate oxidation process (vice versa for the substrate reduction) by mutation is very effective in reducing the thermodynamic overpotential in the intramolecular electron transfer in redox enzymes with multiredox sites (Figure 1). The formal potentials of metallic cofactors such as hemes and copper clusters are predominantly controlled by coordinated amino acid residues. Particularly, the point mutation of the axial ligands of hemes and blue copper clusters can easily tune their formal potentials. The direction of the potential shift depends in part on the electron-donating/accepting characteristics of the mutated amino acid side chains [100,101]. Briefly in general, an axial ligand with a relatively strong electron-donating character shifts the formal potential of the cofactor in the negative potential direction due to the stabilization of the oxidized state of the cofactor and vice versa. The formal potentials of redox enzymes are also greatly interfered with by conformational changes caused by mutated amino acid residues.

FDH is among the accepted model enzymes to investigate the effects of protein engineering on DET-type bioelectrocatalysis. The enzyme is a heterotrimeric enzyme composed of a FAD-containing large catalytic subunit, a three-heme $c$ (called hemes $1 c, 2 c$, and $3 c$ ) from the $\mathrm{N}$-terminus-containing cytochrome subunit, and a small subunit and proceeds with a DET-type reaction by transferring electrons from FAD, heme $3 c$, and heme $2 c$ to an electrode in this order [102-104]. The sixth axial ligand 
(methionine 450 ) of heme $2 c$ was then replaced by glutamine with electron-donating characteristics to shift the formal potential of heme $2 c$ in the direction of the negative potential. The FDH variant (M450Q_FDH) provided DET-type bioelectrocatalytic waves for the oxidation of fructose at a half-wave potential of approximately $50 \mathrm{mV}$, more negative than that of the recombinant native enzyme, as shown in Figure 4A $[103,104]$. A drastic change in the limiting catalytic current was not observed. This suggests that the rate constant of the intramolecular electron transfer from FAD to heme $2 c$ in the enzyme is sufficiently large compared with the catalytic reaction rate constant at the catalytic center (FAD); the latter predominantly determines $k_{\mathrm{c}, \mathrm{DET}}$ in Equation (5).
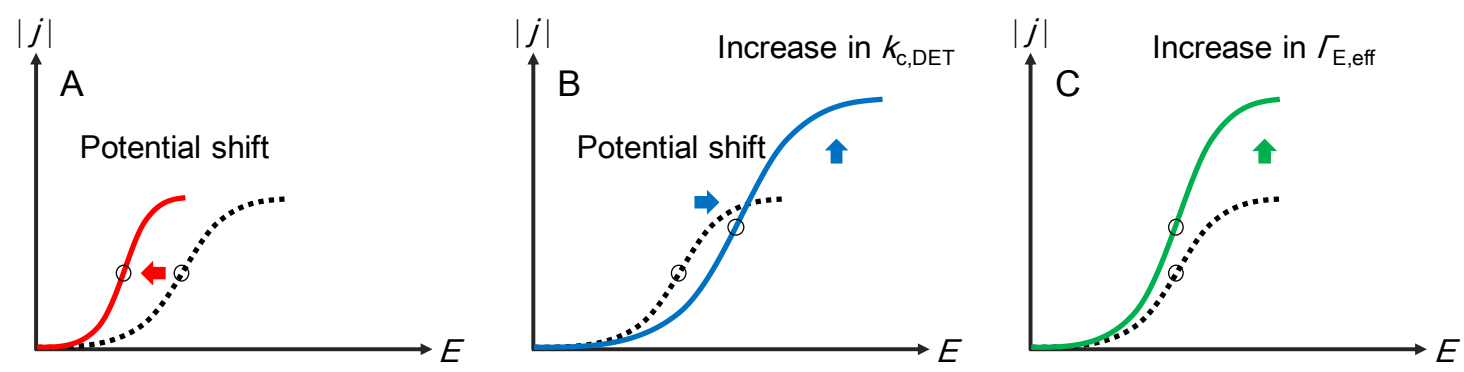

Figure 4. Illustrative drawing of the effect of mutations on steady-state bioelectrocatalytic waves in the DET-type bioelectrocatalysis of "substrate oxidation". (A) Negative potential shift in the formal potential of the electron-donating site of the DET-type redox enzyme reactions, in which the intramolecular electron transfer is not the rate-determining process in the enzymatic catalytic reaction. (B) Positive potential shift in the formal potential of the electron-donating site of the DET-type redox enzyme reactions, in which the intramolecular electron transfer is the rate-determining process in the enzymatic catalytic reaction, and (C) downsizing without any change in the intrinsic enzymatic activity.

On the other hand, such replacement is also effective for the axial ligand of the electron-accepting site (type I blue copper site) to negatively shift the formal potential. Replacement of the axial ligand methionine 467 in the type I copper site of BOD with glutamine (M467Q_BOD) caused a large negative shift (approximately $0.23 \mathrm{~V}$ ) in the half-wave potential of the DET-type bioelectrocatalytic waves. This means an increase in the overpotential in the intramolecular electron transfer in the enzyme. Fortunately, in this case, the catalytic limiting current density increased compared with that of the recombinant native BOD, as shown in Figure 4B (note here that the catalytic wave in Figure 4B is illustrated for substrate oxidation) [105]. Most probably, the catalytic rate constant of the dioxygen reduction at the type II/III catalytic site is sufficiently large compared with the rate constant of the intramolecular electron transfer from the electron-accepting type I site to the dioxygen-reducing type II/III site; the intramolecular electron transfer is the rate-determining step to determine $k_{\mathrm{c}, \mathrm{DET}}$ in Equation (5). In addition, the electron transfer kinetics seems to obey the linear free energy relationship (LFER); the increase in the formal potential difference between type I and II/III sites (that is, the driving force of the reaction) results in an increase in the intramolecular electron transfer rate constant.

Even in MET-type bioelectrocatalysis, the redox potential shift of the electron-donating site (for substrate oxidation) can tune the overpotential in the intramolecular electron transfer process. In addition, the intermolecular electron transfer kinetics between the electron-donating site in the enzyme and the mediator seem to be improved in theory by the potential shift mutation of the electron-donating site (for substrate oxidation) on the basis of the concept of LFER, though there is no report on this matter. Therefore, the mutational tuning of the redox potential of the electron-donating site (for substrate oxidation) may also expand the strategy of the mediator selection for MET-type bioelectrocatalysis.

\subsubsection{Downsizing}

As described by Equation (5), an increase in $\Gamma_{\mathrm{E} \text {,eff }}$ is essential to getting a large bioelectrocatalytic current density. $\Gamma_{\mathrm{E}, \text { eff }}$ can be then increased by downsizing enzymes from which the regions not deeply involved in bioelectrocatalysis are deleted, as shown in Figure $4 \mathrm{C}$. 
Downsizing effects were also investigated in FDH. Heme $1 c$ of FDH is suggested to be uninvolved in the DET-type reaction, and the downsized FDH without the heme $1 c$ region $\left(\Delta 1 c_{-} F D H\right)$ showed a larger DET-type bioelectrocatalytic current density than the recombinant native FDH (r_FDH) $[104,106]$. In addition, a further downsized FDH without the heme $1 c$ and $2 c$ regions ( $\left.\Delta 1 c 2 c \_F D H\right)$ also showed DET-type bioelectrocatalytic activity with reduced overpotential due to direct electrical communication between an electrode and heme $3 c$ with the most negative formal potential $[104,107]$. However, whereas $\Gamma_{\mathrm{E} \text {,eff }}$ was suggested to be increased, $j_{\text {cat }}$ of $\Delta 1 c 2 c \_F D H$ was as large as that of r_FDH (smaller than that of $\Delta 1 c_{-}$FDH), which seemed to be ascribed to a decrease in enzymatic activity $\left(\approx k_{\mathrm{c}, \mathrm{DET}}\right)$ of $\Delta 1 c 2 c_{-} \mathrm{FDH}$ by excessive deletion $[104,107]$. Thus, it is important to avoid conformational changes due to deletion and retain enzymatic activity as high as possible. Furthermore, a double mutant of downsizing and the potential shift (M450Q $\Delta 1 c_{-}$FDH) accomplished both an increase in $j_{\text {cat }}$ and an overpotential reduction $[104,108,109]$.

\subsubsection{Surface Amino Acid Mutation}

It is desirable to tightly immobilize enzymes on electrodes in both DET- and MET-type bioelectrocatalytic reactions. Cross-linkers such as glutaraldehyde [110], carbodiimide [29], and maleimide [71] are often used for the covalent immobilization of enzymes [111]. The mutation of amino acid residue(s) located on the enzyme surface also enhances the cross-coupling reactions and can control the orientation of the enzyme on a suitable electrode surface. For example, cysteine introduction onto the enzyme surface close to the electrode-active site can increase the enzyme orientations suitable for DET-type reactions at thiol- and maleimide-functionalized electrodes by forming (di)sulfide bonds. Holland et al. reported DET-type bioelectrocatalysis of cysteine-introduced GOD conjugated with maleimide-modified gold nanoparticles on a gold electrode [71]. In addition, Ferapontova et al. revealed that cysteine mutation of HRP was effective for its orientation on gold electrodes to improve DET-type bioelectrocatalytic properties [112].

\subsubsection{Fusion Protein}

DET-type bioelectrocatalysis is sometimes achieved by introducing an electrode-active domain into a native enzyme. Cellobiose dehydrogenase $(\mathrm{CDH})$ is often used as a model of DET-type fusion enzymes. $\mathrm{CDH}$ has two domains: a larger catalytic dehydrogenase domain and a smaller electrode-active cytochrome domain. The domains are linked by a flexible polypeptide [113]. The fused cytochrome domain mediates the electron transfer from the catalytic domain to electrodes, such as a "built-in mediator." Utilizing the fusion protein-engineering methods, DET-type reactions by FAD-GDH [114,115], pyrroloquinoline quinone (PQQ)-dependent GDH [116], and flavodoxin [117] were reported.

\section{Novel Bioelectrochemical System}

Major applications in enzymatic bioelectrocatalysis are biosensors and biofuel cells. Biosensors are utilized as analytical devices for food analyses and clinical diagnoses [6-14], and biofuel cells are ecofriendly energy conversion devices in which the chemical energy of fuels is electrically extracted [11,15-21]. The characteristics, properties, and progress of these devices were previously summarized in the corresponding reviews cited above. Recently, in addition, novel methods for bioelectrocatalytic applications are reported as described below.

\subsection{Biosupercapacitor}

Biosupercapacitors are self-powered energy storage devices using bioelectrocatalysis to charge capacitors [22]. In the biosupercapacitor, electric power is generated by a biocathode and/or a bioanode. The fundamental difference between biosupercapacitors and biofuel cells is the separation of the output of the current and bioelectrocatalytic reaction. Expressed as an equivalent circuit, a biosupercapacitor is a biofuel cell and a capacitor connected in parallel. Regardless of the connection to the external circuit, 
the bioelectrocatalytic reaction injects the electrons into the supercapacitor. When the external circuit requires the current, the biosupercapacitor provides the current. An advantage of biosupercapacitors is that a large current can flow even if the kinetics of the bioelectrocatalysis is inadequate. Additionally, biosupercapacitors are compatible with the self-powered biosensors [118,119].

The supercapacitor is classified into two types: the electrical double layer capacitor (EDLC) and the electrochemical pseudocapacitor (EPC). EDLC is the electrode with a large surface area, the electric charge is accumulated in the electrical double layer at the interface between the electrode and the electrolyte solution. EPC is constructed with the electrode and the reversible electrode-active redox species. The externally applied voltage shifts the electrode potential at the anode and a cathode in the negative and positive directions, respectively, as expressed in the Nernst equation.

Generally, redox-active species are immobilized at the electrode surface. Since an electrochemical capacitor contains two electrodes and an electrolyte solution, electrochemical capacitors are also classified into three types: EDLC-EDLC, EPC-EPC, and EDLC-EPC [120]. Therefore, biosupercapacitors are basically classified into the three types. The EDLC is compatible with DET-type bioelectrocatalysis and MET-type bioelectrocatalysis is adapted to the EPC. In order to avoid the mixing of mediators, EPCs in the biosupercapacitor are frequently employed redox polymers as mediators to immobilize at the electrode surface.

Electrochemically inactive porous electrodes in an electrolyte solution work as the EDLC. Additionally, DET-type bioelectrocatalytic activity is required for the EDLC-type biosupercapacitor. The reported materials suitable for the EDLC and the bioelectrode are carbon nanotubes [121-123], porous gold [124], gold nanoparticles [125], and indium tin oxide nanoparticles [126]. Porous electrodes often show high activity for DET-type bioelectrocatalysis. Therefore, it is considered that the investigation of bioelectrodes for DET-type biofuel cells will be directly useful for the biosupercapacitor.

The separation of oxidant and reductant is important in EPCs, since the mixing of the two species causes the cross-reaction discharge. Therefore, in the case of biosupercapacitors using the MET-type bioelectrocatalysis, careful attention is required to head off the outflow of mediators. As mentioned above, redox polymers are employed as mediators in biosupercapacitors [42,127-129]. The immobilization of redox-active proteins at the electrode surface has been investigated for the improvement of the capacitance of EPC-type biosupercapacitors [130,131].

\subsection{Bioelectrosynthesis}

Bioelectrosynthesis is a coined term for the generation of renewable energy resources and useful organic compounds [132]. Particularly, stereoselective enzymatic bioelectrocatalysis is desirable for pharmaceutical use because pharmaceutical precursors are required to have high enantiomeric purity $[133,134]$.

Some useful compounds are reduced forms of redox couples, and reductive conversion is often the opposite reaction in metabolisms in vivo. In bioelectrocatalysis, on the other hand, several enzymes can proceed bidirectional electroenzymatic reactions (both the oxidation and reduction of substrate redox couples), in which the driving forces are reversed depending on $\mathrm{pH}$. For example, $\mathrm{H}_{2}$ ase $[135,136]$, formate dehydrogenase (FoDH) [75,136-139], carbon monoxide dehydrogenase (CODH) [136], diaphorase (DI) [136,140], ferredoxine-NADP ${ }^{+}$reductase (FNR) [28], and some $\mathrm{NAD}(\mathrm{P})^{+}$-dependent dehydrogenases $[28,140-143]$ show bidirectional bioelectrocatalytic activities. The characteristic of these enzymes is that the formal potentials of the substrate redox couples and the cofactors in the enzymes are relatively close to each other, and thus, the small uphill intramolecular electron transfer proceeds in acceptable velocity [34]. Bidirectional bioelectrocatalysis is a key reaction for constructing bioelectrochemical energy/compound conversion systems.

There are mainly two types of bioelectrosynthetic systems: a fuel-cell-type [142,144-149] and an electrolysis-type [28,53,141,143,150-154]. The former realizes a spontaneous production of compounds without any external power supplies, whereas the latter proceeds relatively rapid reactions due to an optimally controlled electrode potential to realize diffusion-controlled conditions. We will show examples of bioelectrosyntheses in the following sections. 


\subsubsection{Dihydrogen Production}

Dihydrogen $\left(\mathrm{H}_{2}\right)$ is a typical clean energy source that emits no harmful products in combustion. $\mathrm{H}_{2}$ ase, a common anodic bioelectrocatalyst for $\mathrm{H}_{2}$ oxidation, can also catalyze proton $\left(\mathrm{H}^{+}\right)$ reduction $[135,136]$. The reversible reaction is biased to favor $\mathrm{H}_{2}$ oxidation, and it is difficult to realize a large cathodic current density of $\mathrm{H}^{+}$reduction in DET-type systems. $\mathrm{H}^{+}$reduction with a large current density was achieved in a $\mathrm{H}_{2}$ ase MET-type system using a viologen polymer as a redox mediator [53]. On the other hand, a dual DET-type bioelectrocatalytic water-gas shift reaction using $\mathrm{CODH}$ and $\mathrm{H}_{2}$ ase $\left(\mathrm{H}_{2} \mathrm{O}+\mathrm{CO} \rightarrow \mathrm{H}_{2}+\mathrm{CO}_{2}\right)$ was reported [146]. The system requires no external power supplies.

\subsubsection{Formate Production}

Formate/formic acid $\left(\mathrm{HCOO}^{-} / \mathrm{HCOOH}\right)$ is a liquid energy resource with a high energy density due to its property of being completely oxidized to $\mathrm{CO}_{2}$. FoDH interconverts $\mathrm{HCOO}^{-}$and $\mathrm{CO}_{2}$ both in DETand MET-type systems [75,136-139]. Sakai et al. reported efficient bioelectrocatalytic $\mathrm{CO}_{2}$ reduction using FoDH from Methylobacterium extorquens AM1 and a synthesized redox mediator with the low formal potential on a gas-diffusion electrode [150]. In addition, spontaneous interconversion between $\mathrm{HCOO}^{-}$and $\mathrm{H}_{2}$ without any external power supplies was achieved by coupling two bioelectrocatalyses by FoDH and $\mathrm{H}_{2}$ ase $\left(\mathrm{H}_{2}+\mathrm{CO}_{2} \rightarrow \mathrm{HCOO}^{-}+\mathrm{H}^{+}\right)$[147]. The direction of the reaction is controlled by $\mathrm{pH}-$ and concentration-dependent equilibrium potentials of the $2 \mathrm{H}^{+} / \mathrm{H}_{2}$ and $\mathrm{CO}_{2} / \mathrm{HCOO}^{-}$couples.

\subsubsection{Ammonia Production}

Ammonia $\left(\mathrm{NH}_{3}\right)$ is an industrially beneficial compound used as a chemical raw material, fuel, hydrogen storage, and so on $[155,156]$. Nitrogenase $\left(\mathrm{N}_{2}\right.$ ase $)$ is an enzyme that catalyzes a nitrogen fixation from dinitrogen $\left(\mathrm{N}_{2}\right)$ to $\mathrm{NH}_{3}$ using adenosine triphosphate (ATP) hydrolysis energy in microorganisms under an anaerobic condition $[155,156]$. Particularly, molybdenum-dependent $\mathrm{N}_{2}$ ase, which comprises a catalytic MoFe protein and a homodimeric MgATP-binding Fe protein, has been mainly investigated in view of bioelectrocatalysis [156,157]. $\mathrm{N}_{2}$ ase reduces not only $\mathrm{N}_{2}$ but also nitrite $\left(\mathrm{NO}_{2}{ }^{-}\right)$and azide $\left(\mathrm{N}_{3}^{-}\right)$to $\mathrm{NH}_{3}$ on electrodes, and the MoFe protein disassociated with the Fe protein shows the DET-type bioelectrocatalytic activity without ATP [154]. Furthermore, ATP-independent $\mathrm{NH}_{3}$ bioelectrosynthesis was improved in the MET-type system using $\mathrm{N}_{2}$ ase and a cobaltocene-functionalized polymeric mediator [51]. On the other hand, Milton et al. reported a $\mathrm{NH}_{3}$-producing $\mathrm{H}_{2} / \mathrm{N}_{2}$ biofuel cell using MET-type reactions of $\mathrm{N}_{2}$ ase and $\mathrm{H}_{2}$ ase [148]. If the fatal weakness of $\mathrm{N}_{2}$ ase, a lack of oxygen tolerance, is improved, $\mathrm{N}_{2}$ ase will be expected to have further industrial applications.

\subsection{4. $\mathrm{NAD}(\mathrm{P})^{+}$-Dependent Bioelectrosynthesis}

Nicotinamide coenzymes $\left(\mathrm{NAD}(\mathrm{P})^{+} / \mathrm{NAD}(\mathrm{P}) \mathrm{H}\right)$ play essential roles in the function of many $\mathrm{NAD}(\mathrm{P})^{+}$-dependent dehydrogenases, but the dehydrogenases need suitable redox mediators in single-step enzymatic bioelectrocatalysis because the $\mathrm{NAD}(\mathrm{P})^{+} / \mathrm{NAD}(\mathrm{P}) \mathrm{H}$ interconversion requires high overpotentials at conventional electrodes due to its hydride ion-transfer-type characteristics that are completely different from two-step single-electron transfer-type electrode reactions. On the other hand, the introduction of dipaphorase (DI) and FNR, which are bioelectrocatalysts for the interconversion of the $\mathrm{NAD}^{+} / \mathrm{NADH}$ and $\mathrm{NADP}^{+} / \mathrm{NADPH}$ redox couples, respectively, can realize various $\mathrm{NAD}(\mathrm{P})^{+}$-dependent bioelectrocatalyses with relatively low overpotentials $[28,140]$.

The bienzymatic MET-type system of $\mathrm{NAD}^{+}$-dependent dehydrogenase and $\mathrm{DI}$ is kinetically and thermodynamically investigated and often applied to biosensors $[40,140,158,159]$. In addition, the coulometric electrooxidation of organic substances was achieved in the same multienzymatic system mimicking the tricarboxylic acid cycle [151]. On the other hand, reductive production of chiral compounds is useful in many cases. Minteer's group reported various NAD ${ }^{+}$-dependent multienzymatic cascade reactions for generating chiral compounds, as shown in Figure 5 [149,152,153]. 
They also demonstrated the bioelectrosynthesis of polyhydroxybutarate with NADH regeneration by DI [143].
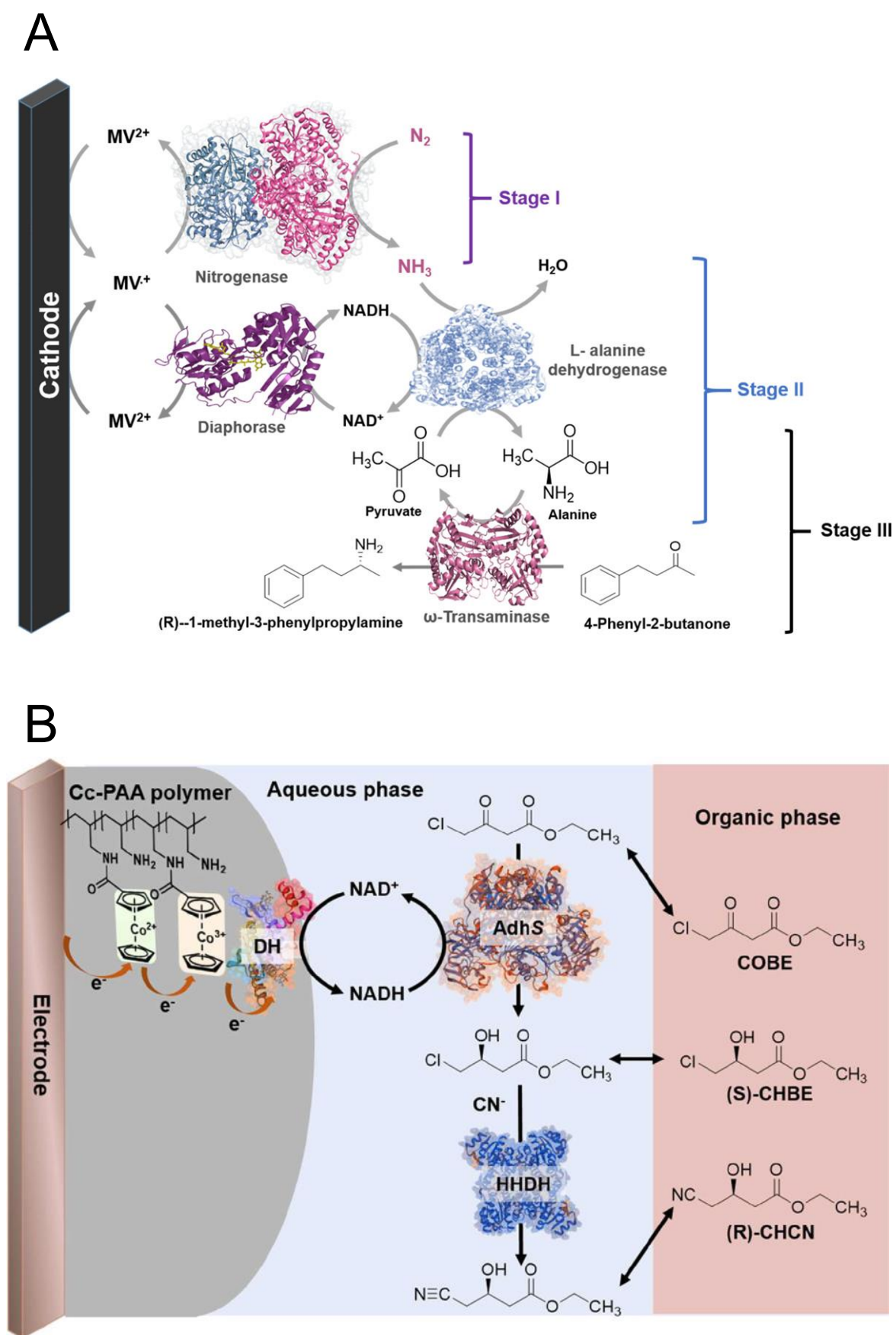

Figure 5. Schematic representation of multienzymatic bioelectrosyntheses of (A) chiral amine and (B) $\beta$-hydroxy nitrile. Abbreviations; DH: diaphorase, AdhS: alcohol dehydrogenase, HHDH: halohydrin dehalogenase, COBE: 4-chloroacetoacetate, CHBE: 4-chloro-3-hydroxybutanoate, $\mathrm{CHCN}$ : ethyl-4-cyano-3-hydroxybutyrate. Reprinted from Ref. [152,153], Copyright $(2019,2020)$, with permission from ACS Publications.

In an $\mathrm{NADP}^{+}$-dependent system, on the other hand, FNR showed DET-type bioelectrocatalytic activity [28]. Particularly, Armstrong's group investigated $\mathrm{NADP}^{+}$-dependent bienzymatic bioelectrocatalysis using FNR. They reported the reductive carboxylation of pyruvate to malate by malate dehydrogenase [142], reductive amination of 2-oxoglutamate to L-glutamate by glutamate 
dehydrogenase $[28,144]$, and enantioselective interconversion of the secondary alcohol/ketone couple by engineered alcohol dehydrogenase [141,145].

\subsection{Photo-Bioelectrocatalysis}

Photo-bioelectrocatalysis enables reducing a substrate with a lower formal potential by oxidizing a sacrificial reagent with a higher formal potential, which cannot spontaneously occur without solar energy. Electrons that photosensitizers accept from sacrificial reagents are excited by solar energy, and the electric potential is shifted in the negative direction, corresponding to the wavelength of the adsorbed light. The electrons are then donated to substrates via enzymes and mediators, as shown in Figure 6. Photosensitizers such as $\mathrm{TiO}_{2}[80,81,160-162]$, PbS quantum dots [162], silver nanoclusters [80,81], and organic dyes [160,161] are incorporated in anodes of transparent electrode bases (ITO in general) with or without other catalysts. Particularly, in addition, the photosystem II (PSII) complex in the thylakoid membrane of cyanobacteria and higher plants is often used as a water-splitting anodic photo-bioelectrocatalyst [129,160-181]. Biosolar cells [163-173] and solar biosupercapacitors [129,164,168,174], using PSII/I, thylakoid membranes, or cyanobacteria in anodes, and BOD or laccase in cathodes, realized the conversion from solar to electric energy without any sacrificial reagents in total. On the other hand, photo-bioelectrosyntheses, also called artificial photosyntheses, are reported. $\mathrm{H}_{2}$ is generated by $\mathrm{H}_{2}$ ase $[80,160]$, and $\mathrm{CO}_{2}$ is fixed by $\mathrm{FoDH}$ and $\mathrm{CODH}[81,161]$. These cathodic reactions proceed at quite low potentials. Thus, in order to improve the Faradaic efficiency of these photo-bioelectrosyntheses, it is essential to reduce electron leakage to dissolved oxygen as much as possible, especially when oxygen-generating photosynthetic proteins or organisms are used as anodic photo-bioelectrocatalysts.

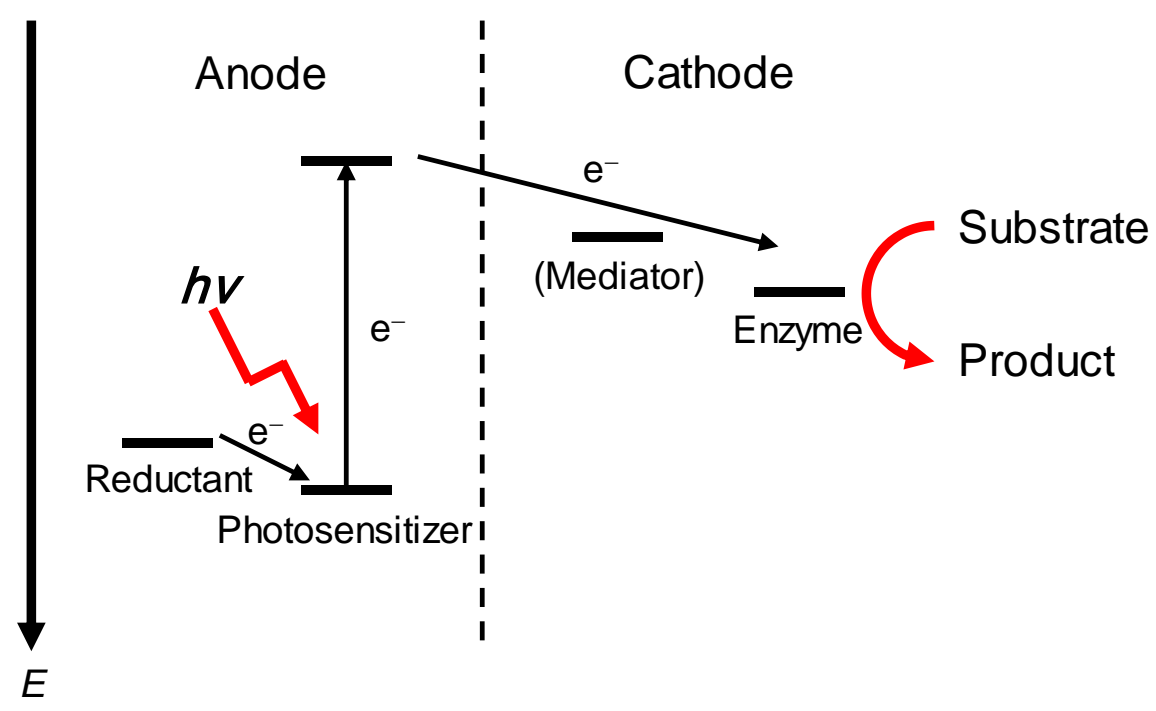

Figure 6. Potential profile in a simple photo-bioelectrocatalytic system.

\section{Conclusions}

Enzymatic bioelectrocatalysis is advancing day by day due to the finding of novel enzymes and the development of electrode nanomaterials. However, there are still issues to be solved such as thermostability, oxygen tolerance, and physical fragility, compared to inorganic electrocatalysts. Further understanding and consideration of the electrode interface and the interaction between enzymes and electrodes from kinetics and thermodynamics are required. Other perspectives, such as the improvement of redox enzymes by protein-engineering approaches, the selection of electrode materials and mediators (including redox hydrogels), the immobilization of enzymes, and the layout of electrodes will be also required for the improvement of present bioelectrochemical devices. 
Author Contributions: Conceptualization, T.A. and K.K.; data curation, T.A.; writing-original draft preparation, T.A.; writing-review and editing, Y.K., O.S. and K.K.; supervision, K.K.; project administration, K.K. All authors have read and agreed to the published version of the manuscript.

Funding: This research received no external funding.

Conflicts of Interest: The authors declare no conflict of interest.

\section{References}

1. Bartlett, P.N. Bioelectrochemistry: Fundamentals, Experimental Techniques and Applications; John Wiley \& Sons: Chichester, UK, 2008.

2. Wilson, G.S.; Johnson, M.A. In-Vivo Electrochemistry: What Can We Learn about Living Systems? Chem. Rev. 2008, 108, 2462-2481. [CrossRef]

3. Heller, A. Electrical connection of enzyme redox centers to electrodes. J. Phys. Chem. 1992, 96, 3579-3587. [CrossRef]

4. Kano, K. Fundamentals and Applications of Redox Enzyme-functionalized Electrode Reactions. Electrochemistry 2019, 87, 301-311. [CrossRef]

5. Scheller, F.; Kirstein, D.; Schubert, F.; Wollenberger, U.; Ollson, B.; Gorton, L.; Johansson, G. Enzyme electrodes and their application. Philos. Trans. R. Soc. B Biol. Sci. 1987, 316, 85-94. [CrossRef]

6. Thevenot, D.R.; Tóth, K.; Durst, R.A.; Wilson, G.S. Electrochemical Biosensors: Recommended Definitions and Classification. Pure Appl. Chem. 1999, 71, 2333-2348. [CrossRef]

7. Martinkova, P.; Kostelnik, A.; Valek, T.; Pohanska, M. Main streams in the Construction of Biosensors and Their Applications. Int. J. Electrochem. Sci. 2017, 12, 7386-7403. [CrossRef]

8. Bollella, P.; Gorton, L. Enzyme based amperometric biosensors. Curr. Opin. Electrochem. 2018, 10, $157-173$. [CrossRef]

9. Kucherenko, I.S.; Soldatkin, A.; Kucherenko, D.Y.; Soldatkina, O.V.; Dzyadevych, S.V. Advances in nanomaterial application in enzyme-based electrochemical biosensors: A review. Nanoscale Adv. 2019, 1, 4560-4577. [CrossRef]

10. Nguyen, H.H.; Lee, S.H.; Lee, U.J.; Fermin, C.D.; Kim, M. Immobilized Enzymes in Biosensor Applications. Materials 2019, 12, 121. [CrossRef]

11. Pinyou, P.; Blay, V.; Muresan, L.M.; Noguer, T. Enzyme-modified electrodes for biosensors and biofuel cells. Mater. Horiz. 2019, 6, 1336-1358. [CrossRef]

12. Bollella, P.; Katz, E. Enzyme-Based Biosensors: Tackling Electron Transfer Issues. Sensors 2020, $20,3517$. [CrossRef] [PubMed]

13. Willner, I.; Katz, E.; Willner, B. Electrical contact of redox enzyme layers associated with electrodes: Routes to amperometric biosensors. Electroanalysis 1997, 9, 965-977. [CrossRef]

14. Scheller, F.; Schubert, F.; Pfeiffer, D.; Hintsche, R.; Dransfeld, I.; Renneberg, R.; Wollenberger, U.; Riedel, K.; Pavlova, M.; Kühn, M.; et al. Research and development of biosensors. A review. Analyst 1989, 114, 653-662. [CrossRef] [PubMed]

15. De Poulpiquet, A.; Ranava, D.; Monsalve, K.; Giudici-Orticoni, M.-T.; Lojou, E. Biohydrogen for a New Generation of H2/O2Biofuel Cells: A Sustainable Energy Perspective. ChemElectroChem 2014, 1, 1724-1750. [CrossRef]

16. Barton, S.C.; Gallaway, J.; Atanassov, P. Enzymatic Biofuel Cells for Implantable and Microscale Devices. Chem. Rev. 2004, 104, 4867-4886. [CrossRef]

17. Cracknell, J.A.; Vincent, K.A.; Armstrong, F.A. Enzymes as Working or Inspirational Electrocatalysts for Fuel Cells and Electrolysis. Chem. Rev. 2008, 108, 2439-2461. [CrossRef]

18. Meredith, M.T.; Minteer, S.D. Biofuel Cells: Enhanced Enzymatic Bioelectrocatalysis. Annu. Rev. Anal. Chem. 2012, 5, 157-179. [CrossRef]

19. Mazurenko, I.; De Poulpiquet, A.; Lojou, E. Recent developments in high surface area bioelectrodes for enzymatic fuel cells. Curr. Opin. Electrochem. 2017, 5, 74-84. [CrossRef]

20. Mano, N.; De Poulpiquet, A. O2Reduction in Enzymatic Biofuel Cells. Chem. Rev. 2018, 118, $2392-2468$. [CrossRef]

21. Xiao, X.; Xia, H.-Q.; Wu, R.; Bai, L.; Yan, L.; Magner, E.; Cosnier, S.; Lojou, E.; Zhu, Z.; Liu, A. Tackling the Challenges of Enzymatic (Bio)Fuel Cells. Chem. Rev. 2019, 119, 9509-9558. [CrossRef] 
22. Shleev, S.; González-Arribas, E.; Falk, M. Biosupercapacitors. Curr. Opin. Electrochem. 2017, 5, $226-233$. [CrossRef]

23. Krieg, T.; Sydow, A.; Schröder, U.; Schrader, J.; Holtmann, D. Reactor concepts for bioelectrochemical syntheses and energy conversion. Trends Biotechnol. 2014, 32, 645-655. [CrossRef] [PubMed]

24. Paddock, R.M.; Bowden, E.F. Electrocatalytic reduction of hydrogen peroxide via direct electron transfer from pyrolytic graphite electrodes to irreversibly adsorbed cytochrome c peroxidase. J. Electroanal. Chem. Interfacial Electrochem. 1989, 260, 487-494. [CrossRef]

25. Xia, H.; Kitazumi, Y.; Shirai, O.; Kano, K. Direct Electron Transfer-type Bioelectrocatalysis of Peroxidase at Mesoporous Carbon Electrodes and Its Application for Glucose Determination Based on Bienzyme System. Anal. Sci. 2017, 33, 839-844. [CrossRef] [PubMed]

26. Gu, T.; Wang, J.; Xia, H.; Wang, S.; Yu, X. Direct Electrochemistry and Electrocatalysis of Horseradish Peroxidase Immobilized in a DNA/Chitosan-Fe3O4 Magnetic Nanoparticle Bio-Complex Film. Materials 2014, 7, 1069-1083. [CrossRef]

27. Sakai, K.; Kitazumi, Y.; Shirai, O.; Kano, K. Nanostructured Porous Electrodes by the Anodization of Gold for an Application as Scaffolds in Direct-electron-transfer-type Bioelectrocatalysis. Anal. Sci. 2018, 34, 1317-1322. [CrossRef]

28. Siritanaratkul, B.; Megarity, C.F.; Roberts, T.G.; Samuels, T.O.M.; Winkler, M.; Warner, J.H.; Happe, T.; Armstrong, F.A. Transfer of photosynthetic NADP+/NADPH recycling activity to a porous metal oxide for highly specific, electrochemically-driven organic synthesis. Chem. Sci. 2017, 8, 4579-4586. [CrossRef]

29. Yehezkeli, O.; Raichlin, S.; Tel-Vered, R.; Kesselman, E.; Danino, D.; Willner, I. Biocatalytic Implant of Pt Nanoclusters into Glucose Oxidase: A Method to Electrically Wire the Enzyme and to Transform It from an Oxidase to a Hydrogenase. J. Phys. Chem. Lett. 2010, 1, 2816-2819. [CrossRef]

30. Trifonov, A.; Stemmer, A.; Tel-Vered, R. Enzymatic self-wiring in nanopores and its application in direct electron transfer biofuel cells. Nanoscale Adv. 2019, 1, 347-356. [CrossRef]

31. Adachi, T.; Fujii, T.; Honda, M.; Kitazumi, Y.; Shirai, O.; Kano, K. Direct electron transfer-type bioelectrocatalysis of FAD-dependent glucose dehydrogenase using porous gold electrodes and enzymatically implanted platinum nanoclusters. Bioelectrochemistry 2020, 133, 107457. [CrossRef]

32. Léger, C.; Bertrand, P. Direct Electrochemistry of Redox Enzymes as a Tool for Mechanistic Studies. Chem. Rev. 2008, 108, 2379-2438. [CrossRef] [PubMed]

33. Milton, R.D.; Minteer, S.D. Direct enzymatic bioelectrocatalysis: Differentiating between myth and reality. J. R. Soc. Interface 2017, 14, 20170253. [CrossRef] [PubMed]

34. Adachi, T.; Kitazumi, Y.; Shirai, O.; Kano, K. Direct Electron Transfer-Type Bioelectrocatalysis of Redox Enzymes at Nanostructured Electrodes. Catalysts 2020, 10, 236. [CrossRef]

35. Kitazumi, Y.; Shirai, O.; Kano, K. Catalyst Materials for Bioelectrochemical Systems: Fundamentals and Applications; ACS Publications: Washington, DC, USA, 2020; pp. 147-163.

36. Gorton, L.; Jönsson-Pettersson, G.; Csöregi, E.; Johansson, K.; Domínguez, E.; Marko-Varga, G. Amperometric biosensors based on an apparent direct electron transfer between electrodes and immobilized peroxidases. Plenary lecture. Analyst 1992, 117, 1235-1241. [CrossRef]

37. Degani, Y.; Heller, A. Electrical communication between redox centers of glucose oxidase and electrodes via electrostatically and covalently bound redox polymers. J. Am. Chem. Soc. 1989, 111, 2357-2358. [CrossRef]

38. Ohara, T.J.; Rajagopalan, R.; Heller, A. Glucose Electrodes Based on Cross-Linked (Os(bpy)2Cl) $+/ 2+$ Complexed Poly(1-vinylimidazole) Films. Anal. Chem. 1993, 65, 3512-3517. [CrossRef]

39. Timur, S.; Yigzaw, Y.; Gorton, L. Electrical wiring of pyranose oxidase with osmium redox polymers. Sens. Actuators B Chem. 2006, 113, 684-691. [CrossRef]

40. Nikitina, O.; Shleev, S.; Gayda, G.; Demkiv, O.; Gonchar, M.; Gorton, L.; Csöregi, E.; Nistor, M. Bi-enzyme biosensor based on $\mathrm{NAD}^{+}$- and glutathione-dependent recombinant formaldehyde dehydrogenase and diaphorase for formaldehyde assay. Sens. Actuators B Chem. 2007, 125, 1-9. [CrossRef]

41. Nieh, C.-H.; Kitazumi, Y.; Shirai, O.; Yamamoto, M.; Kano, K. Potentiometric coulometry based on charge accumulation with a peroxidase/osmium polymer-immobilized electrode for sensitive determination of hydrogen peroxide. Electrochem. Commun. 2013, 33, 135-137. [CrossRef]

42. Alsaoub, S.; Conzuelo, F.; Gounel, S.; Mano, N.; Schuhmann, W.; Ruff, A. Introducing Pseudocapavitive Bioelectrodes into a Biofuel Cell/Biosupercapacitor Hybrid Device for Optimized Open Circuit Voltage. ChemElectroChem 2019, 6, 2080-2087. [CrossRef] 
43. Tsujimura, S.; Takeuchi, S. Toward an Ideal Platform Structure Based on MgO-Templated Carbon for Flavin Adenine Dinucleotide-Dependent Glucose Dehydrogenase-Os Polymer-Hydrogel Electrodes. Electrochim. Acta 2020, 343, 136110. [CrossRef]

44. Xiao, X.; Conghaile, P.Ó.; Leech, D.; Magner, E. Use of Polymer Coatings to Enhance the Response of Redox-Polymer-Mediated Electrodes. ChemElectroChem 2019, 6, 1344-1349. [CrossRef]

45. Čènas, N.K.; Pocius, A.K.; Kulys, J.J. Electron Exchange between Flavin- and Heme-Containing Enzymes and Electrodes Modified by Redox Polymers. Bioelectrochem. Bioenerg. 1983, 11, 61-73. [CrossRef]

46. Nieh, C.-H.; Kitazumi, Y.; Shirai, O.; Kano, K. Sensitive d-amino acid biosensor based on oxidase/peroxidase system mediated by pentacyanoferrate-bound polymer. Biosens. Bioelectron. 2013, 47, 350-355. [CrossRef] [PubMed]

47. Nieh, C.-H.; Tsujimura, S.; Shirai, O.; Kano, K. Amperometric biosensor based on reductive H2O2 detection using pentacyanoferrate-bound polymer for creatinine determination. Anal. Chim. Acta 2013, 767, 128-133. [CrossRef]

48. Merchant, S.A.; Meredith, M.T.; Tran, T.O.; Brunski, D.B.; Johnson, M.B.; Glatzhofer, D.T.; Schmidtke, D.W. Effect of Mediator Spacing on Electrochemical and Enzymatic Response of Ferrocene Redox Polymers. J. Phys. Chem. C 2010, 114, 11627-11634. [CrossRef]

49. Tran, T.O.; Lammert, E.G.; Chen, J.; Merchant, S.A.; Brunski, D.B.; Keay, J.C.; Johnson, M.B.; Glatzhofer, D.T.; Schmidtke, D.W. Incorporation of Single-Walled Carbon Nanotubes into Ferrocene-Modified Linear Polyethylenimine Redox Polymer Films. Langmuir 2011, 27, 6201-6210. [CrossRef]

50. Milton, R.D.; Abdellaoui, S.; Khadka, N.; Dean, D.R.; Leech, D.; Seefeldt, L.C.; Minteer, S.D. Nitrogenase bioelectrocatalysis: Heterogeneous ammonia and hydrogen production by MoFe protein. Energy Environ. Sci. 2016, 9, 2550-2554. [CrossRef]

51. Lee, Y.S.; Yuan, M.; Cai, R.; Lim, K.; Minteer, S.D. Nitrogenase Bioelectrocatalysis: ATP-Independent Ammonia Production Using a Redox Polymer/MoFe Protein System. ACS Catal. 2020, 10, 6854-6861. [CrossRef]

52. Eng, L.H.; Elmgren, M.; Komlos, P.; Nordling, M.; Lindquist, S.-E.; Neujahr, H.Y. Viologen-Based Redox Polymer for Contacting the Low-Potential Redox Enzyme Hydrogenase at an Electrode Surface. J. Phys. Chem. 1994, 98, 7068-7072. [CrossRef]

53. Shiraiwa, S.; So, K.; Sugimoto, Y.; Kitazumi, Y.; Shirai, O.; Kano, K. Reactivation of Standard (NiFe)-Hydrogenase and Bioelectrochemical Catalysis of Proton Reduction and Hydrogen Oxidation in a Mediated-Electron-Transfer System. Bioelectrochemistry 2018, 123, 156-161. [CrossRef]

54. Sakai, K.; Kitazumi, Y.; Shirai, O.; Kano, K. Bioelectrocatalytic formate oxidation and carbon dioxide reduction at high current density and low overpotential with tungsten-containing formate dehydrogenase and mediators. Electrochem. Commun. 2016, 65, 31-34. [CrossRef]

55. Sakai, K.; Kitazumi, Y.; Shirai, O.; Takagi, K.; Kano, K. High-Power Formate/Dioxygen Biofuel Cell Based on Mediated Electron Transfer Type Bioelectrocatalysis. ACS Catal. 2017, 7, 5668-5673. [CrossRef]

56. Kitazumi, Y.; Shirai, O.; Yamamoto, M.; Kano, K. Numerical simulation of diffuse double layer around microporous electrodes based on the Poisson-Boltzmann equation. Electrochim. Acta 2013, 112, 171-175. [CrossRef]

57. Serafin, V.; Hernández, P.; Agüí, L.; Yáñez-Sedeño, P.; Pingarrón, J.M. Electrochemical Biosensor for Creatinine Based on the Immobilization of Creatininase, Creatinase and Sarcosine Oxidase onto a Ferrocene/Horseradish Peroxidase/Gold Nanoparticles/Multi-Walled Carbon Nanotubes/Teflon Composite Electrode. Electrochim. Acta 2013, 97, 175-183. [CrossRef]

58. Holzinger, M.; Le Goff, A.; Cosnier, S. Carbon nanotube/enzyme biofuel cells. Electrochim. Acta 2012, 82, 179-190. [CrossRef]

59. Tominaga, M.; Sasaki, A.; Togami, M. Laccase Bioelectrocatalyst at a Steroid-Type Biosurfactant-Modified Carbon Nanotube Interface. Anal. Chem. 2015, 87, 5417-5421. [CrossRef]

60. Tsujimura, S.; Nishina, A.; Kamitaka, Y.; Kano, K. Coulometric D-Fructose Biosensor Based on Direct Electron Transfer Using D-Fructose Dehydrogenase. Anal. Chem. 2009, 81, 9383-9387. [CrossRef]

61. Flexer, V.; Durand, F.; Tsujimura, S.; Mano, N. Efficient Direct Electron Transfer of PQQ-glucose Dehydrogenase on Carbon Cryogel Electrodes at Neutral pH. Anal. Chem. 2011, 83, 5721-5727. [CrossRef]

62. Hamano, Y.; Tsujimura, S.; Shirai, O.; Kano, K. Micro-cubic monolithic carbon cryogel electrode for direct electron transfer reaction of fructose dehydrogenase. Bioelectrochemistry 2012, 88, 114-117. [CrossRef] 
63. Murata, K.; Akatsuka, W.; Tsujimura, S. Bioelectrocatalytic Oxidation of Glucose on MgO-templated Mesoporous Carbon-modified Electrode. Chem. Lett. 2014, 43, 928-930. [CrossRef]

64. Mazurenko, I.; Clément, R.; Byrne-Kodjabachian, D.; de Poulpiquet, A.; Tsujimura, S.; Lojou, E. Pore Size Effect of MgO-Templated Carbon on Enzymatic $\mathrm{H}_{2}$ Oxidation by the Hyperthermophilic Hydrogenase from Aquifex aeolicus. J. Electroanal. Chem. 2018, 812, 221-226. [CrossRef]

65. Takahashi, Y.; Wanibuchi, M.; Kitazumi, Y.; Shirai, O.; Kano, K. Improved direct electron transfer-type bioelectrocatalysis of bilirubin oxidase using porous gold electrodes. J. Electroanal. Chem. 2019, 843, 47-53. [CrossRef]

66. Mie, Y.; Yasutake, Y.; Ikegami, M.; Tamura, T. Anodized gold surface enables mediator-free and low-overpotential electrochemical oxidation of NADH: A facile method for the development of an NAD+-dependent enzyme biosensor. Sens. Actuators B Chem. 2019, 288, 512-518. [CrossRef]

67. Miyata, M.; Kitazumi, Y.; Shirai, O.; Kataoka, K.; Kano, K. Diffusion-limited biosensing of dissolved oxygen by direct electron transfer-type bioelectrocatalysis of multi-copper oxidases immobilized on porous gold microelectrodes. J. Electroanal. Chem. 2020, 860, 113895. [CrossRef]

68. Siepenkoetter, T.; Salaj-Kosla, U.; Xiao, X.; Belochapkine, S.; Magner, E. Nanoporous Gold Electrodes with Tuneable Pore Sizes for Bioelectrochemical Applications. Electroanalysis 2016, 28, 2415-2423. [CrossRef]

69. Siepenkoetter, T.; Salaj-Kosla, U.; Magner, E. The Immobilization of Fructose Dehydrogenase on Nanoporous Gold Electrodes for the Detection of Fructose. ChemElectroChem 2017, 4, 905-912. [CrossRef]

70. Xiao, X.; Siepenkoetter, T.; Conghaile, P.Ó.; Leech, D.; Magner, E. Nanoporous Gold-Based Biofuel Cells on Contact Lenses. ACS Appl. Mater. Interfaces 2018, 10, 7107-7116. [CrossRef] [PubMed]

71. Holland, J.T.; Lau, C.; Brozik, S.; Atanassov, P.; Banta, S. Engineering of Glucose Oxidase for Direct Electron Transfer via Site-Specific Gold Nanoparticle Conjugation. J. Am. Chem. Soc. 2011, 133, 19262-19265. [CrossRef] [PubMed]

72. Gutiérrez-Sánchez, C.; Pita, M.; Vaz-Domínguez, C.; Shleev, S.; De Lacey, A.L. Gold Nanoparticles as Electronic Bridges for Laccase-Based Biocathodes. J. Am. Chem. Soc. 2012, 134, 17212-17220. [CrossRef]

73. Suzuki, M.; Murata, K.; Nakamura, N.; Ohno, H. The Effect of Particle Size on the Direct Electron Transfer Reactions of Metalloproteins Using Au Nanoparticle-Modified Electrodes. Electrochemistry 2012, 80, 337-339. [CrossRef]

74. Monsalve, K.; Roger, M.; Gutierrez-Sanchez, C.; Ilbert, M.; Nitsche, S.; Byrne-Kodjabachian, D.; Marchi, V.; Lojou, E. Hydrogen bioelectrooxidation on gold nanoparticle-based electrodes modified by Aquifex aeolicus hydrogenase: Application to hydrogen/oxygen enzymatic biofuel cells. Bioelectrochemistry 2015, 106, 47-55. [CrossRef] [PubMed]

75. Sakai, K.; Kitazumi, Y.; Shirai, O.; Takagi, K.; Kano, K. Direct Electron Transfer-Type Four-Way Bioelectrocatalysis of $\mathrm{CO}_{2}$ /Formate and $\mathrm{NAD}^{+} / \mathrm{NADH}$ Redox Couples by Tungsten-Containing Formate Dehydrogenase Adsorbed on Gold Nanoparticle-Embedded Mesoporous Carbon Electrodes Modified with 4-Mercaptopyridine. Electrochem. Commun. 2017, 84, 75-79. [CrossRef]

76. Takahashi, Y.; Kitazumi, Y.; Shirai, O.; Kano, K. Improved direct electron transfer-type bioelectrocatalysis of bilirubin oxidase using thiol-modified gold nanoparticles on mesoporous carbon electrode. J. Electroanal. Chem. 2019, 832, 158-164. [CrossRef]

77. Hitaishi, V.P.; Mazurenko, I.; Murali, A.V.; De Poulpiquet, A.; Coustillier, G.; Delaporte, P.; Lojou, E. Nanosecond Laser-Fabricated Monolayer of Gold Nanoparticles on ITO for Bioelectrocatalysis. Front. Chem. 2020, 8, 431. [CrossRef]

78. Kizling, M.; Dzwonek, M.; Więckowska, A.; Bilewicz, R. Gold nanoparticles in bioelectrocatalysis-The role of nanoparticle size. Curr. Opin. Electrochem. 2018, 12, 113-120. [CrossRef]

79. Murata, K.; Suzuki, M.; Nakamura, N.; Ohno, H. Direct evidence of electron flow via the heme c group for the direct electron transfer reaction of fructose dehydrogenase using a silver nanoparticle-modified electrode. Electrochem. Commun. 2009, 11, 1623-1626. [CrossRef]

80. Zhang, L.; Beaton, S.E.; Carr, S.B.; Armstrong, F.A. Direct visible light activation of a surface cysteine-engineered [NiFe]-hydrogenase by silver nanoclusters. Energy Environ. Sci. 2018, 11, 3342-3348. [CrossRef]

81. Zhang, L.; Can, M.; Ragsdale, S.W.; Armstrong, F. Fast and Selective Photoreduction of $\mathrm{CO}_{2}$ to $\mathrm{CO}$ Catalyzed by a Complex of Carbon Monoxide Dehydrogenase, $\mathrm{TiO}_{2}$, and Ag Nanoclusters. ACS Catal. 2018, 8 , 2789-2795. [CrossRef] 
82. Nakamura, R.; Kamiya, K.; Hashimoto, K. Direct electron-transfer conduits constructed at the interface between multicopper oxidase and nanocrystalline semiconductive Fe oxides. Chem. Phys. Lett. 2010, 498, 307-311. [CrossRef]

83. Kizling, M.; Rekorajska, A.; Krysinski, P.; Bilewicz, R. Magnetic-field-induced orientation of fructose dehydrogenase on iron oxide nanoparticles for enhanced direct electron transfer. Electrochem. Commun. 2018, 93, 66-70. [CrossRef]

84. Rozniecka, E.; Jonsson-Niedziolka, M.; Sobczak, J.W.; Opallo, M. Mediatorless bioelectrocatalysis of dioxygen reduction at indium-doped tin oxide (ITO) and ITO nanoparticulate film electrodes. Electrochim. Acta 2011, 56, 8739-8745. [CrossRef]

85. Willner, I.; Katz, E. Integration of Layered Redox Proteins and Conductive Supports for Bioelectronic Applications. Angew. Chem. Int. Ed. 2000, 39, 1180-1218. [CrossRef]

86. Moser, C.C.; Keske, J.M.; Warncke, K.; Farid, R.S.; Dutton, P.L. Nature of biological electron transfer. Nat. Cell Biol. 1992, 355, 796-802. [CrossRef] [PubMed]

87. Marcus, R.; Sutin, N. Electron transfers in chemistry and biology. Biochim. Biophys. Acta BBA Rev. Bioenerg. 1985, 811, 265-322. [CrossRef]

88. Marcus, R.A. Electron Transfer Reactions in Chemistry: Theory and Experiment (Nobel Lecture). Angew. Chem. Int. Ed. 1993, 32, 1111-1121. [CrossRef]

89. Sugimoto, Y.; Takeuchi, R.; Kitazumi, Y.; Shirai, O.; Kano, K. Significance of Mesoporous Electrodes for Noncatalytic Faradaic Process of Randomly Oriented Redox Proteins. J. Phys. Chem. C 2016, 120, 26270-26277. [CrossRef]

90. Sugimoto, Y.; Kitazumi, Y.; Shirai, O.; Kano, K. Effects of Mesoporous Structures on Direct Electron Transfer-Type Bioelectrocatalysis: Facts and Simulation on a Three-Dimensional Model of Random Orientation of Enzymes. Electrochemistry 2017, 85, 82-87. [CrossRef]

91. Hitaishi, V.P.; Clement, R.; Bourassin, N.; Baaden, M.; De Poulpiquet, A.; Sacquin-Mora, S.; Ciaccafava, A.; Sacquin-Mora, S. Controlling Redox Enzyme Orientation at Planar Electrodes. Catalysts 2018, 8, 192. [CrossRef]

92. Xia, H.; So, K.; Kitazumi, Y.; Shirai, O.; Nishikawa, K.; Higuchi, Y.; Kano, K. Dual gas-diffusion membraneand mediatorless dihydrogen/air-breathing biofuel cell operating at room temperature. J. Power Sources 2016, 335, 105-112. [CrossRef]

93. Adachi, T.; Kitazumi, Y.; Shirai, O.; Kawano, T.; Kataoka, K.; Kano, K. Effects of Elimination of $\alpha$ Helix Regions on Direct Electron Transfer-type Bioelectrocatalytic Properties of Copper Efflux Oxidase. Electrochemistry 2020, 88, 185-189. [CrossRef]

94. Xia, H.; Kitazumi, Y.; Shirai, O.; Kano, K. Enhanced direct electron transfer-type bioelectrocatalysis of bilirubin oxidase on negatively charged aromatic compound-modified carbon electrode. J. Electroanal. Chem. 2016, 763, 104-109. [CrossRef]

95. So, K.; Kawai, S.; Hamano, Y.; Kitazumi, Y.; Shirai, O.; Hibi, M.; Ogawa, J.; Kano, K. Improvement of a direct electron transfer-type fructose/dioxygen biofuel cell with a substrate-modified biocathode. Phys. Chem. Chem. Phys. 2014, 16, 4823-4829. [CrossRef] [PubMed]

96. Bollella, P.; Hibino, Y.; Kano, K.; Gorton, L.; Antiochia, R. Highly Sensitive Membraneless Fructose Biosensor Based on Fructose Dehydrogenase Immobilized onto Aryl Thiol Modified Highly Porous Gold Electrode: Characterization and Application in Food Samples. Anal. Chem. 2018, 90, 12131-12136. [CrossRef] [PubMed]

97. Xia, H.; Hibino, Y.; Kitazumi, Y.; Shirai, O.; Kano, K. Interaction between d-fructose dehydrogenase and methoxy-substituent-functionalized carbon surface to increase productive orientations. Electrochim. Acta 2016, 218, 41-46. [CrossRef]

98. So, K.; Sakai, K.; Kano, K. Gas diffusion bioelectrodes. Curr. Opin. Electrochem. 2017, 5, 173-182. [CrossRef]

99. Wong, T.S.; Schwaneberg, U. Protein engineering in bioelectrocatalysis. Curr. Opin. Biotechnol. 2003, 14, 590-596. [CrossRef]

100. Battistuzzi, G.; Borsari, M.; Cowan, J.A.; Ranieri, A.; Sola, M. Control of cytochrome C redox potential: Axial ligation and protein environment effects. J. Am. Chem. Soc. 2002, 124, 5315-5324. [CrossRef]

101. Li, H.; Webb, S.P.; Ivanic, J.; Jensen, J.H. Determinants of the Relative Reduction Potentials of Type-1 Copper Sites in Proteins. J. Am. Chem. Soc. 2004, 126, 8010-8019. [CrossRef]

102. Kawai, S.; Yakushi, T.; Matsushita, K.; Kitazumi, Y.; Shirai, O.; Kano, K. The electron transfer pathway in direct electrochemical communication of fructose dehydrogenase with electrodes. Electrochem. Commun. 2014, 38, 28-31. [CrossRef] 
103. Hibino, Y.; Kawai, S.; Kitazumi, Y.; Shirai, O.; Kano, K. Mutation of heme c axial ligands in d-fructose dehydrogenase for investigation of electron transfer pathways and reduction of overpotential in direct electron transfer-type bioelectrocatalysis. Electrochem. Commun. 2016, 67, 43-46. [CrossRef]

104. Adachi, T.; Kaida, Y.; Kitazumi, Y.; Shirai, O.; Kano, K. Bioelectrocatalytic performance of d-fructose dehydrogenase. Bioelectrochemistry 2019, 129, 1-9. [CrossRef] [PubMed]

105. Kamitaka, Y.; Tsujimura, S.; Kataoka, K.; Sakurai, T.; Ikeda, T.; Kano, K. Effects of axial ligand mutation of the type I copper site in bilirubin oxidase on direct electron transfer-type bioelectrocatalytic reduction of dioxygen. J. Electroanal. Chem. 2007, 601, 119-124. [CrossRef]

106. Hibino, Y.; Kawai, S.; Kitazumi, Y.; Shirai, O.; Kano, K. Construction of a protein-engineered variant of d -fructose dehydrogenase for direct electron transfer-type bioelectrocatalysis. Electrochem. Commun. 2017, 77, 112-115. [CrossRef]

107. Kaida, Y.; Hibino, Y.; Kitazumi, Y.; Shirai, O.; Kano, K. Ultimate downsizing of d-fructose dehydrogenase for improving the performance of direct electron transfer-type bioelectrocatalysis. Electrochem. Commun. 2019, 98, 101-105. [CrossRef]

108. Hibino, Y.; Kawai, S.; Kitazumi, Y.; Shirai, O.; Kano, K. Protein-Engineering Improvement of Direct Electron Transfer-Type Bioelectrocatalytic Properties of d-Fructose Dehydrogenase. Electrochemistry 2019, 87, 47-51. [CrossRef]

109. Kaida, Y.; Hibino, Y.; Kitazumi, Y.; Shirai, O.; Kano, K. Discussion on Direct Electron Transfer-Type Bioelectrocatalysis of Downsized and Axial-Ligand Exchanged Variants of d-Fructose Dehydrogenase. Electrochemistry 2020, 88, 195-199. [CrossRef]

110. Matsui, Y.; Hamamoto, K.; Kitazumi, Y.; Shirai, O.; Kano, K. Diffusion-Controlled Mediated Electron Transfer-Type Bioelectrocatalysis Using Ultrathin-Ring and Microband Electrodes as Ultimate Amperometric Glucose Sensors. Anal. Sci. 2017, 33, 845-851. [CrossRef]

111. Mazurenko, I.; Hitaishi, V.P.; Lojou, E. Recent advances in surface chemistry of electrodes to promote direct enzymatic bioelectrocatalysis. Curr. Opin. Electrochem. 2020, 19, 113-121. [CrossRef]

112. Ferapontova, E.E.; Schmengler, K.; Börchers, T.; Ruzgas, T.; Gorton, L. Effect of cysteine mutations on direct electron transfer of horseradish peroxidase on gold. Biosens. Bioelectron. 2002, 17, 953-963. [CrossRef]

113. Bollella, P.; Ludwig, R.; Gorton, L. Cellobiose dehydrogenase: Insights on the nanostructuration of electrodes for improved development of biosensors and biofuel cells. Appl. Mater. Today 2017, 9, 319-332. [CrossRef]

114. Algov, I.; Grushka, J.; Zarivach, R.; Alfonta, L. Highly Efficient Flavin-Adenine Dinucleotide Glucose Dehydrogenase Fused to a Minimal Cytochrome C Domain. J. Am. Chem. Soc. 2017, 139, 17217-17220. [CrossRef] [PubMed]

115. Ito, K.; Okuda-Shimazaki, J.; Mori, K.; Kojima, K.; Tsugawa, W.; Ikebukuro, K.; Lin, C.-E.; La Belle, J.T.; Yoshida, H.; Sode, K. Designer fungus FAD glucose dehydrogenase capable of direct electron transfer. Biosens. Bioelectron. 2019, 123, 114-123. [CrossRef] [PubMed]

116. Okuda, J.; Sode, K. PQQ glucose dehydrogenase with novel electron transfer ability. Biochem. Biophys. Res. Commun. 2004, 314, 793-797. [CrossRef]

117. Gilardi, G.; Meharenna, Y.T.; Tsotsou, G.E.; Sadeghi, S.J.; Fairhead, M.; Giannini, S. Molecular Lego: Design of molecular assemblies of P450 enzymes for nanobiotechnology. Biosens. Bioelectron. 2002, 17, 133-145. [CrossRef]

118. Hanashi, T.; Yamazaki, T.; Tsugawa, W.; Ferri, S.; Nakayama, D.; Tomiyama, M.; Ikebukuro, K.; Sode, K. BioCapacitor-A Novel Category of Biosensor. Biosens. Bioelectron. 2009, 24, 1837-1842. [CrossRef]

119. Conzuelo, F.; Ruff, A.; Schuhmann, W. Self-powered bioelectrochemical devices. Curr. Opin. Electrochem. 2018, 12, 156-163. [CrossRef]

120. Falk, M.; Shleev, S. Hybrid Dual-functioning Electrodes for Combined Ambient Energy Harvesting and Charge Strage: Towards Self-Powered Systems. Biosens. Bioelectron. 2019, 126, 275-291. [CrossRef]

121. Agnès, C.; Holzinger, M.; Le Goff, A.; Reuillard, B.; Elouarzaki, K.; Tingry, S.; Cosnier, S. Supercapacitor/biofuel cell hybrids based on wired enzymes on carbon nanotube matrices: Autonomous reloading after high power pulses in neutral buffered glucose solutions. Energy Environ. Sci. 2014, 7, 1884-1888. [CrossRef]

122. Pankratov, D.; Blum, Z.; Suyatin, D.B.; Popov, V.O.; Shleev, S. Self-Charging Electrochemical Biocapacitor. ChemElectroChem 2013, 1, 343-346. [CrossRef]

123. Pankratov, D.; Blum, Z.; Shleev, S. Hybrid Electric Power Biodevices. ChemElectroChem 2014, 1, $1798-1807$. [CrossRef] 
124. Xiao, X.; Magner, E. A quasi-solid-state and self-powered biosupercapacitor based on flexible nanoporous gold electrodes. Chem. Commun. 2018, 54, 5823-5826. [CrossRef] [PubMed]

125. Pankratov, D.; Shen, F.; Ortiz, R.; Toscano, M.D.; Thormann, E.; Zhang, J.; Gorton, L.; Chi, Q. Fuel-independent and membrane-less self-charging biosupercapacitor. Chem. Commun. 2018, 54, 11801-11804. [CrossRef] [PubMed]

126. Bobrowski, T.; González-Arribas, E.; Ludwig, R.; Toscano, M.D.; Shleev, S.; Schuhmann, W. Rechargeable, Flexible and Mediator-Free Biosupercapacitor Based on Transparent ITO Nanoparticle Modified Electrodes Acting in $\mu \mathrm{M}$ Glucose Containing Buffers. Biosens. Bioelectron. 2018, 101, 84-89. [CrossRef]

127. Pankratov, D.; Conzuelo, F.; Pinyou, P.; Alsaoub, S.; Schuhmann, W.; Shleev, S. A Nernstian Biosupercapacitor. Angew. Chem. Int. Ed. 2016, 55, 15434-15438. [CrossRef]

128. Alsaoub, S.; Ruff, A.; Conzuelo, F.; Ventosa, E.; Ludwig, R.; Shleev, S.; Schuhmann, W. An Intrinsic Self-Charging Biosupercapacitor Comprised of a High-Potential Bioanode and a Low-Potential Biocathode. ChemPlusChem 2017, 82, 576-583. [CrossRef]

129. Zhao, F.; Bobrowski, T.; Ruff, A.; Hartmann, V.; Nowaczyk, M.M.; Rögner, M.; Conzuelo, F.; Schuhmann, W. A light-driven Nernstian biosupercapacitor. Electrochim. Acta 2019, 306, 660-666. [CrossRef]

130. González-Arribas, E.; Falk, M.; Aleksejeva, O.; Bushnev, S.; Sebastián, P.; Feliu, J.M.; Shleev, S. A Conventional Symmetric Biosupercapacitor Based on Rusticyanin Modified Gold Electrodes. J. Electroanal. Chem. 2018, 816, 253-258. [CrossRef]

131. Shen, F.; Pankratov, D.; Pankratova, G.; Toscano, M.D.; Zhang, J.; Ulstrup, J.; Chi, Q.; Gorton, L. Supercapacitor/Biofuel Cell Hybrid Device Employing Biomolecules for Energy Conversion and Charge Stroge. Bioelectrochemistry 2019, 128, 94-99. [CrossRef]

132. Wu, R.; Ma, C.; Zhu, Z. Enzymatic electrosynthesis as an emerging electrochemical synthesis platform. Curr. Opin. Electrochem. 2020, 19, 1-7. [CrossRef]

133. Schmid, A.I.; Dordick, J.S.; Hauer, B.; Kiener, A.; Wubbolts, M.; Witholt, B. Industrial biocatalysis today and tomorrow. Nat. Cell Biol. 2001, 409, 258-268. [CrossRef] [PubMed]

134. Zaks, A. Industrial biocatalysis. Curr. Opin. Chem. Biol. 2001, 5, 130-136. [CrossRef]

135. Vincent, K.A.; Parkin, A.; Armstrong, F.A. Investigating and Exploiting the Electrocatalytic Properties of Hydrogenases. Chem. Rev. 2007, 107, 4366-4413. [CrossRef] [PubMed]

136. Armstrong, F.; Hirst, J. Reversibility and efficiency in electrocatalytic energy conversion and lessons from enzymes. Proc. Natl. Acad. Sci. USA 2011, 108, 14049-14054. [CrossRef] [PubMed]

137. Sakai, K.; Hsieh, B.-C.; Maruyama, A.; Kitazumi, Y.; Shirai, O.; Kano, K. Interconversion between formate and hydrogen carbonate by tungsten-containing formate dehydrogenase-catalyzed mediated bioelectrocatalysis. Sens. Bio Sens. Res. 2015, 5, 90-96. [CrossRef]

138. Reda, T.; Plugge, C.M.; Abram, N.J.; Hirst, J. Reversible interconversion of carbon dioxide and formate by an electroactive enzyme. Proc. Natl. Acad. Sci. USA 2008, 105, 10654-10658. [CrossRef]

139. Bassegoda, A.; Madden, C.; Wakerley, D.W.; Reisner, E.; Hirst, J. Reversible Interconversion of $\mathrm{CO}_{2}$ and Formate by a Molybdenum-Containing Formate Dehydrogenase. J. Am. Chem. Soc. 2014, 136, 15473-15476. [CrossRef]

140. Takagi, K.; Kano, K.; Ikeda, T. Mediated bioelectrocatalysis based on NAD-related enzymes with reversible characteristics. J. Electroanal. Chem. 1998, 445, 211-219. [CrossRef]

141. Megarity, C.F.; Siritanaratkul, B.; Heath, R.S.; Wan, L.; Morello, G.; Fitzpatrick, S.R.; Booth, R.L.; Sills, A.J.; Robertson, A.W.; Warner, J.H.; et al. Electrocatalytic Volleyball: Rapid Nanoconfined Nicotinamide Cycling for Organic Synthesis in Electrode Pores. Angew. Chem. Int. Ed. 2019, 58, 4948-4952. [CrossRef]

142. Morello, G.; Siritanaratkul, B.; Megarity, C.F.; Armstrong, F.A. Efficient Electrocatalytic $\mathrm{CO}_{2}$ Fixation by Nanoconfined Enzymes via a C3-to-C4 Reaction That Is Favored over $\mathrm{H}_{2}$ Production. ACS Catal. 2019, 9, 11255-11262. [CrossRef]

143. Alkotaini, B.; Abdellaoui, S.; Hasan, K.; Grattieri, M.; Quah, T.; Cai, R.; Yuan, M.; Minteer, S.D. Sustainable Bioelectrosynthesis of the Bioplastic Polyhydroxybutyrate: Overcoming Substrate Requirement for NADH Regeneration. ACS Sustain. Chem. Eng. 2018, 6, 4909-4915. [CrossRef]

144. Wan, L.; Megarity, C.F.; Siritanaratkul, B.; Armstrong, F. A hydrogen fuel cell for rapid, enzyme-catalysed organic synthesis with continuous monitoring. Chem. Commun. 2018, 54, 972-975. [CrossRef] [PubMed] 
145. Wan, L.; Heath, R.S.; Siritanaratkul, B.; Megarity, C.F.; Sills, A.J.; Thompson, M.P.; Turner, N.J.; Armstrong, F. Enzyme-catalysed enantioselective oxidation of alcohols by air exploiting fast electrochemical nicotinamide cycling in electrode nanopores. Green Chem. 2019, 21, 4958-4963. [CrossRef]

146. Lazarus, O.; Woolerton, T.W.; Parkin, A.; Lukey, M.J.; Reisner, E.; Seravalli, J.; Pierce, E.; Ragsdale, S.W.; Sargent, F; Armstrong, F.A. Water-Gas Shift Reaction Catalyzed by Redox Enzymes on Conducting Graphite Platelets. J. Am. Chem. Soc. 2009, 131, 14154-14155. [CrossRef] [PubMed]

147. Adachi, T.; Kitazumi, Y.; Shirai, O.; Kano, K. Construction of a bioelectrochemical formate generating system from carbon dioxide and dihydrogen. Electrochem. Commun. 2018, 97, 73-76. [CrossRef]

148. Milton, R.D.; Cai, R.; Abdellaoui, S.; Leech, D.; De Lacey, A.L.; Pita, M.; Minteer, S.D. Bioelectrochemical Haber-Bosch Process: An Ammonia-Producing $\mathrm{H}_{2} / \mathrm{N}_{2}$ Fuel Cell. Angew. Chem. Int. Ed. 2017, 56, 2680-2683. [CrossRef] [PubMed]

149. Chen, H.; Prater, M.B.; Cai, R.; Dong, F.; Chen, H.; Minteer, S.D. Bioelectrocatalytic Conversion from $\mathrm{N}_{2}$ to Chiral Amino Acids in a $\mathrm{H}_{2} / \alpha$-Keto Acid Enzymatic Fuel Cell. J. Am. Chem. Soc. 2020, 142, 4028-4036. [CrossRef]

150. Sakai, K.; Kitazumi, Y.; Shirai, O.; Takagi, K.; Kano, K. Efficient bioelectrocatalytic $\mathrm{CO}_{2}$ reduction on gas-diffusion-type biocathode with tungsten-containing formate dehydrogenase. Electrochem. Commun. 2016, 73, 85-88. [CrossRef]

151. Fukuda, J.; Tsujimura, S.; Kano, K. Coulometric bioelectrocatalytic reactions based on NAD-dependent dehydrogenases in tricarboxylic acid cycle. Electrochim. Acta 2008, 54, 328-333. [CrossRef]

152. Chen, H.; Cai, R.; Patel, J.; Dong, F.; Chen, H.; Minteer, S.D. Upgraded Bioelectrocatalytic $\mathrm{N}_{2}$ Fixation: From N2 to Chiral Amine Intermediates. J. Am. Chem. Soc. 2019, 141, 4963-4971. [CrossRef]

153. Dong, F.; Chen, H.; Malapit, C.A.; Prater, M.B.; Li, M.; Yuan, M.; Lim, K.; Minteer, S.D. Biphasic Bioelectrocatalytic Synthesis of Chiral $\beta$-Hydroxy Nitriles. J. Am. Chem. Soc. 2020, 142, 8374-8382. [CrossRef] [PubMed]

154. Hickey, D.P.; Cai, R.; Yang, Z.-Y.; Grunau, K.; Einsle, O.; Seefeldt, L.C.; Minteer, S.D. Establishing a Thermodynamic Landscape for the Active Site of Mo-Dependent Nitrogenase. J. Am. Chem. Soc. 2019, 141, 17150-17157. [CrossRef] [PubMed]

155. Smith, B.E. STRUCTURE: Nitrogenase Reveals Its Inner Secrets. Science 2002, 297, 1654-1655. [CrossRef] [PubMed]

156. Milton, R.D.; Minteer, S.D. Enzymatic Bioelectrosynthetic Ammonia Production: Recent Electrochemistry of Nitrogenase, Nitrate Reductase, and Nitrite Reductase. ChemPlusChem 2016, 82, 513-521. [CrossRef]

157. Cai, R.; Minteer, S.D. Nitrogenase Bioelectrocatalysis: From Understanding Electron-Transfer Mechanisms to Energy Applications. ACS Energy Lett. 2018, 3, 2736-2742. [CrossRef]

158. Antiochia, R.; Gallina, A.; Lavagnini, I.; Magno, F. Kinetic and Thermodynamic Aspects of NAD-Related Enzyme-Linked Mediated Bioelectrocatalysis. Electroanalysis 2002, 14, 1256-1261. [CrossRef]

159. Lobo, M.J.; Miranda, A.J.; Tuñón, P. Amperometric Biosensors Based on NAD(P)-Dependent Dehydrogenase Enzymes. Electroanalysis 1997, 9, 191-201. [CrossRef]

160. Sokol, K.P.; Robinson, W.E.; Warnan, J.; Kornienko, N.; Nowaczyk, M.M.; Ruff, A.; Zhang, J.Z.; Reisner, E. Bias-free photoelectrochemical water splitting with photosystem II on a dye-sensitized photoanode wired to hydrogenase. Nat. Energy 2018, 3, 944-951. [CrossRef]

161. Sokol, K.P.; Robinson, W.E.; Oliveira, A.R.; Warnan, J.; Nowaczyk, M.M.; Ruff, A.; Pereira, I.A.C.; Reisner, E. Photoreduction of $\mathrm{CO}_{2}$ with a Formate Dehydrogenase Driven by Photosystem II Using a Semi-artificial Z-Scheme Architecture. J. Am. Chem. Soc. 2018, 140, 16418-16422. [CrossRef]

162. Riedel, M.; Wersig, J.; Ruff, A.; Schuhmann, W.; Zouni, A.; Lisdat, F. A Z-Scheme-Inspired Photobioelectrochemical $\mathrm{H}_{2} \mathrm{O} / \mathrm{O}_{2}$ Cell with a $1 V$ Open-Circuit Voltage Combining Photosystem II and PbS Quantum Dots. Angew. Chem. Int. Ed. 2019, 58, 801-805. [CrossRef]

163. Adachi, T.; Kataoka, K.; Kitazumi, Y.; Shirai, O.; Kano, K. A Bio-solar Cell with Thylakoid Membranes and Bilirubin Oxidase. Chem. Lett. 2019, 48, 686-689. [CrossRef]

164. Pankratov, D.; Pankratova, G.; Dyachkova, T.P.; Falkman, P.; Åkerlund,H.-E.; Toscano, M.D.; Chi, Q.; Gorton, L . Supercapacitive Biosolar Cell Driven by Direct Electron Transfer between Photosynthetic Membranes and CNT Networks with Enhanced Performance. ACS Energy Lett. 2017, 2, 2635-2639. [CrossRef]

165. Rasmussen, M.; Wingersky, A.; Minteer, S.D. Improved Performance of a Thylakoid Bio-Solar Cell by Incorporation of Carbon Quantum Dots. ECS Electrochem. Lett. 2013, 3, H1-H3. [CrossRef] 
166. Efrati, A.; Tel-Vered, R.; Michaeli, R.; Nechushtai, R.; Willner, I. Cytochrome c-coupled photosystem I and photosystem II (PSI/PSII) photo-bioelectrochemical cells. Energy Environ. Sci. 2013, 6, 2950. [CrossRef]

167. Kirchhofer, N.D.; Rasmussen, M.; Dahlquist, F.W.; Minteer, S.D.; Bazan, G.C. The photobioelectrochemical activity of thylakoid bioanodes is increased via photocurrent generation and improved contacts by membrane-intercalating conjugated oligoelectrolytes. Energy Environ. Sci. 2015, 8, 2698-2706. [CrossRef]

168. Pankratova, G.; Pankratov, D.; Hasan, K.; Åkerlund, H.-E.; Albertsson, P.-Å.; Leech, D.; Shleev, S.; Gorton, L. Supercapacitive Photo-Bioanodes and Biosolar Cells: A Novel Approach for Solar Energy Harnessing. Adv. Energy Mater. 2017, 7, 1602285. [CrossRef]

169. Yehezkeli, O.; Tel-Vered, R.; Wasserman, J.; Trifonov, A.; Michaeli, D.; Nechushtai, R.; Willner, I. Integrated photosystem II-based photo-bioelectrochemical cells. Nat. Commun. 2012, 3, 742. [CrossRef]

170. Calkins, J.O.; Umasankar, Y.; O’Neill, H.; Ramasamy, R.P. High photo-electrochemical activity of thylakoid-carbon nanotube composites for photosynthetic energy conversion. Energy Environ. Sci. 2013, 6, 1891-1900. [CrossRef]

171. Tsujimura, S.; Wadano, A.; Kano, K.; Ikeda, T. Photosynthetic bioelectrochemical cell utilizing cyanobacteria and water-generating oxidase. Enzym. Microb. Technol. 2001, 29, 225-231. [CrossRef]

172. Mimcault, M.; Carpentier, R. Kinetics of Photocurrent Induction by a Thylakoid Containing Elctrochemical Cell. J. Electroanal. Chem. 1989, 276, 145-158. [CrossRef]

173. Carpentier, R.; Lemieux, S.; Mimeault, M.; Purcell, M.; Goetze, D.C. A Photoelectrochemical Cell Using Immobilized Photosynthetic Membranes. J. Electroanal. Chem. Interfacial Electrochem. 1989, 276, 391-401. [CrossRef]

174. González-Arribas, E.; Aleksejeva, O.; Bobrowski, T.; Toscano, M.D.; Gorton, L.; Schuhmann, W.; Shleev, S. Solar biosupercapacitor. Electrochem. Commun. 2017, 74, 9-13. [CrossRef]

175. Rasmussen, M.; Minteer, S.D. Investigating the Mechanism of Thylakoid Direct Electron Transfer for Photocurrent Generation. Electrochim. Acta 2014, 126, 68-73. [CrossRef]

176. Saboe, P.O.; Conte, E.; Chan, S.; Feroz, H.; Ferlez, B.; Farell, M.; Poyton, M.F.; Sines, I.T.; Yan, H.; Bazan, G.C.; et al. Biomimetic wiring and stabilization of photosynthetic membrane proteins with block copolymer interfaces. J. Mater. Chem. A 2016, 4, 15457-15463. [CrossRef]

177. Kanso, H.; Pankratova, G.; Bollella, P.; Leech, D.; Hernandez, D.; Gorton, L. Sunlight photocurrent generation from thylakoid membranes on gold nanoparticle modified screen-printed electrodes. J. Electroanal. Chem. 2018, 816, 259-264. [CrossRef]

178. Hamidi, H.; Hasan, K.; Emek, S.C.; Dilgin, Y.; Åkerlund, H.-E.; Albertsson, P.-. Åke; Leech, D.; Gorton, L. Photocurrent Generation from Thylakoid Membranes on Osmium-Redox-Polymer-Modified Electrodes. ChemSusChem 2015, 8, 990-993. [CrossRef] [PubMed]

179. Hasan, K.; Milton, R.D.; Grattieri, M.; Wang, T.; Stephanz, M.; Minteer, S.D. Photobioelectrocatalysis of Intact Chloroplasts for Solar Energy Conversion. ACS Catal. 2017, 7, 2257-2265. [CrossRef]

180. Takeuchi, R.; Suzuki, A.; Sakai, K.; Kitazumi, Y.; Shirai, O.; Kano, K. Construction of photo-driven bioanodes using thylakoid membranes and multi-walled carbon nanotubes. Bioelectrochemistry 2018, 122, 158-163. [CrossRef]

181. Hasan, K.; Dilgin, Y.; Emek, S.C.; Tavahodi, M.; Åkerlund, H.-E.; Albertsson, P.-Å.; Gorton, L. Photoelectrochemical Communication between Thylakoid Membranes and Gold Electrodes through Different Quinone Derivatives. ChemElectroChem 2014, 1, 131-139. [CrossRef]

Publisher's Note: MDPI stays neutral with regard to jurisdictional claims in published maps and institutional affiliations.

(C) 2020 by the authors. Licensee MDPI, Basel, Switzerland. This article is an open access article distributed under the terms and conditions of the Creative Commons Attribution (CC BY) license (http://creativecommons.org/licenses/by/4.0/). 